\title{
Endogenous collagen peptide activation of CD1d-restricted NKT cells ameliorates tissue-specific inflammation in mice
}

\author{
Yawei Liu, ${ }^{1,2}$ Anna Teige, ${ }^{2}$ Emma Mondoc,,$^{2,3,4}$ Saleh Ibrahim, ${ }^{5}$ \\ Rikard Holmdahl,3,4 and Shohreh Issazadeh-Navikas',2
}

\begin{abstract}
${ }^{1}$ Neuroinflammation Unit, Biotech Research and Innovation Centre, University of Copenhagen, Denmark. ${ }^{2}$ Neuroinflammation Unit, University of Lund Lund, Sweden. ${ }^{3}$ Medical Inflammation Research, Department of Medical Biochemistry and Biophysics, Karolinska Institutet, Stockholm, Sweden. ${ }^{4}$ Medical Inflammation Research, University of Lund, Lund, Sweden. ${ }^{5}$ mmunogenetics Group, University of Rostock, Rostock, Germany.
\end{abstract}

\begin{abstract}
NKT cells in the mouse recognize antigen in the context of the MHC class I-like molecule CD1d and play an important role in peripheral tolerance and protection against autoimmune and other diseases. NKT cells are usually activated by CD1d-presented lipid antigens. However, peptide recognition in the context of CD1 has also been documented, although no self-peptide ligands have been reported to date. Here, we have identified an endogenous peptide that is presented by CD1d to activate mouse NKT cells. This peptide, the immunodominant epitope from mouse collagen type II ( $\left.\mathrm{mCII}_{707-721}\right)$, was not associated with either MHC class I or II. Activation of CD1d-restricted $\mathrm{mCII}_{707-721}$-specific $\mathrm{NKT}$ cells was induced via TCR signaling and classical costimulation. In addition, $\mathrm{mCII}_{707-721}$-specific $\mathrm{NKT}$ cells induced $\mathrm{T}$ cell death through Fas/FasL, in an IL-17Aindependent fashion. Moreover, $\mathrm{mCII}_{707-721}-$ specific $\mathrm{NKT}$ cells suppressed a range of in vivo inflammatory conditions, including delayed-type hypersensitivity, antigen-induced airway inflammation, collagen-induced arthritis, and EAE, which were all ameliorated by $\mathbf{m C I I}_{\text {707-721 }}$ vaccination. The findings presented here offer new insight into the intrinsic roles of NKT cells in health and disease. Given the results, endogenous collagen peptide activators of NKT cells may offer promise as novel therapeutics in tissue-specific autoimmune and inflammatory diseases.
\end{abstract}

\section{Introduction}

The immune system responds to invading pathogens by recognizing their antigenic structures, while remaining unresponsive to self antigens. This simplified model, however, is challenged by the understanding that autoreactivity is a common feature of healthy organisms and a part of peripheral tolerance mechanisms. To generate animal models for autoimmune diseases, susceptible species are often immunized with self antigens. However, not all immunogenic self antigens have the capacity to provoke a pathogenic autoimmune response, and some of them confer protection (1). A widely accepted animal model for human rheumatoid arthritis is collageninduced arthritis (CIA) in mice. CIA is induced by immunizing susceptible mouse strains with cartilage-derived triple helical type II collagen (CII). In mice expressing the MHC class II molecule H-2Aq, the disease-mediating epitope is an immunodominant glycopeptide derived from position 260-270 of rat CII (2). In comparison with heterologous CII, mouse CII, although capable of inducing arthritis, provokes a much weaker immune response to the immunodominant epitope and induces a lower incidence of arthritis (3). However, mouse CII immunization induces a recall proliferative response toward multiple epitopes in addition to the MHC class II-restricted $\mathrm{CII}_{260-270}$ peptide (4). The major epitopes share a common motif, with the strongest located at position 707-721 $\left(\mathrm{mCII}_{707-721}\right)$. By investigating the immune response to this epitope, surprisingly, we found that this peptide was not MHC I/II restricted, but was binding and presented by CD1d, a cluster of

Authorship note: Yawei Liu and Anna Teige contributed equally to this work. Conflict of interest: The authors have declared that no conflict of interest exists. Citation for this article: J Clin Invest. 2011;121(1):249-264. doi:10.1172/JCI43964 differentiation glycoprotein. This led to the identification of a population of NKT cells that responded to $\mathrm{mCII}_{707-721}$ and were CD1d-restricted, TCR $\alpha \beta^{+} \mathrm{CD} 4^{+} \mathrm{NK} 1.1^{+}$cells.

$\mathrm{CD} 1 \mathrm{~d}$ is an alternative, MHC class I-like glycoprotein that presents antigens to NKT cells. The most extensively described population of CD1d-restricted NKT cells are reactive to the exogenous glycolipid $\alpha$-galactosylceramide ( $\alpha$ GalCer) (5). An endogenous ligand, isoglobotrihexosylceramide, has been shown to be involved in NKT cell autoreactivity (6). In addition to the association of CD1d with the binding and/or presentation of self and exogenous lipid or glycolipids (6), early reports have also indicated peptidepresenting capacity of CD1d (7-9).

Although the regulatory function of NKT cells is debated $(5,10)$, reports over the past decade have shown that both foreign and self-lipid-reactive CD1d-restricted NKT cells can regulate autoimmune diseases, moderate graft rejection, assist in host defense against infection, and promote tumor rejection, in spite of their relatively small population size (10-13). The immune regulatory function of CD1d-restricted NKT cells is ascribed to their capacity for rapidly releasing large quantities of cytokines, including IL-4 and IFN- $\gamma$ (10). In the current report, we show that the $\mathrm{mCII}_{707-721}$-specific NKT cells are competent to produce IL-4, IFN- $\gamma$, IL-17A, TNF- $\alpha$, and TGF- $\beta$ upon peptide stimulation. However, the regulatory function of $\mathrm{mCII}_{707-721^{-}}$ specific NKT cells is likely through the Fas-FasL-mediated killing of activated $\mathrm{T}$ cells, not by cytokine production. Prevaccination with the $\mathrm{mCII}_{707-721}$ peptide resulted in downregulation of both Th1- and Th2-mediated immune responses and tissue inflammation in vivo. To our knowledge, this is the first report showing the existence of a CD1d-presented endogenous peptide 


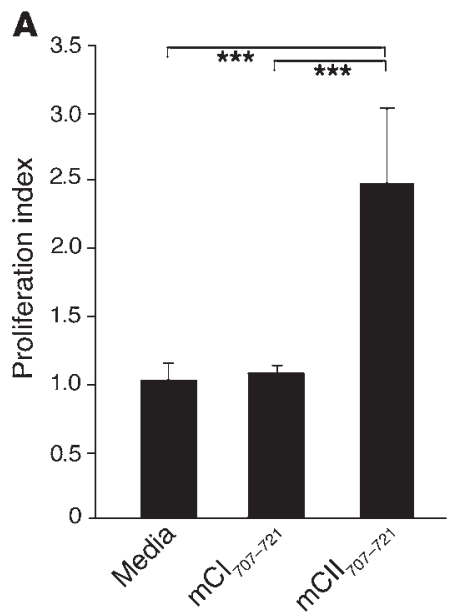

C

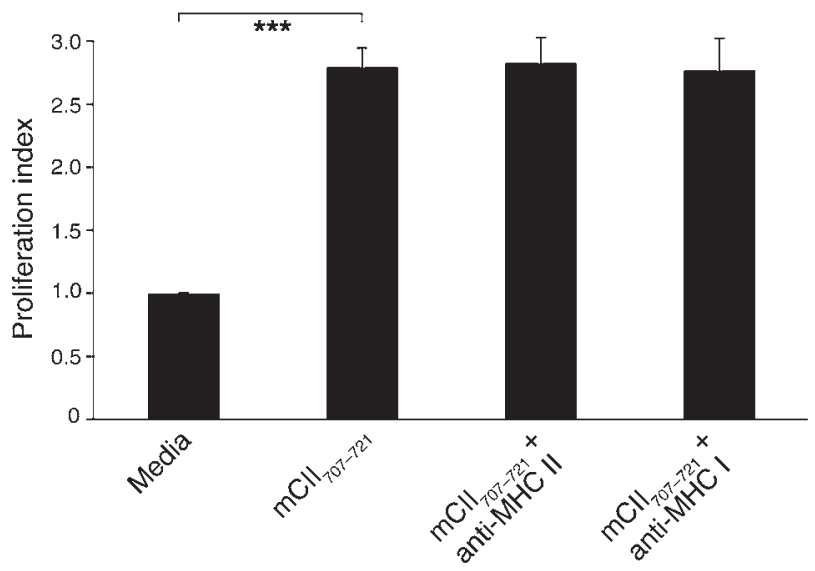

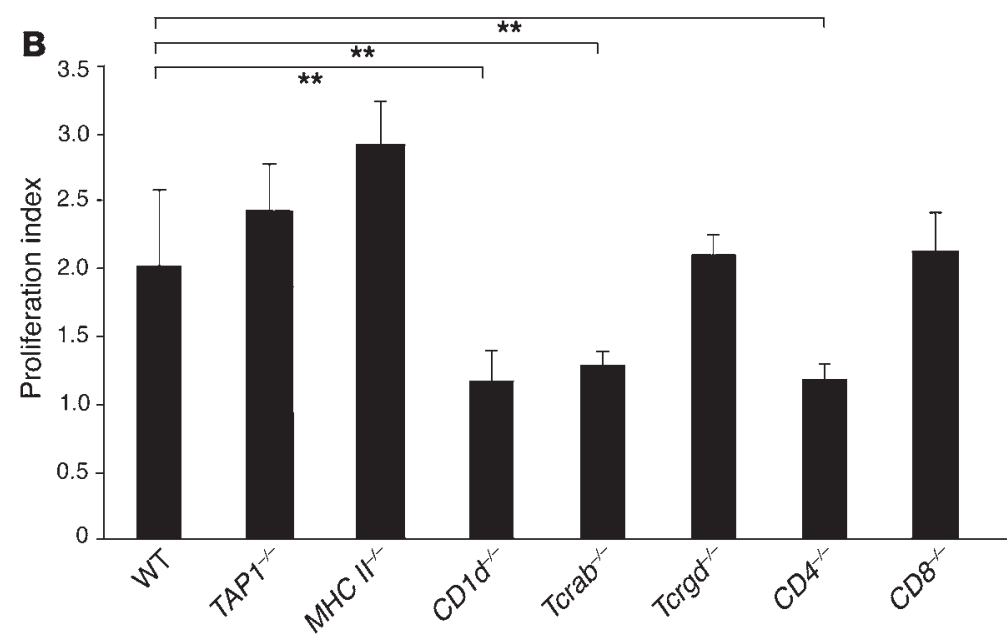

D

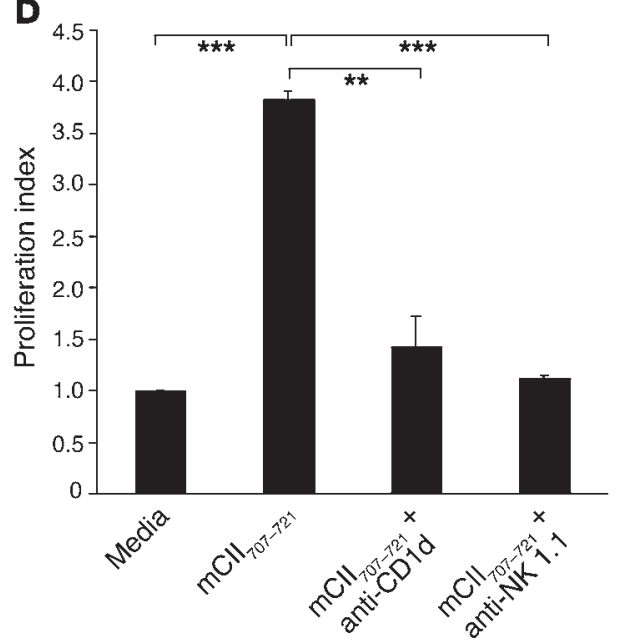

Figure 1

Immunodominant mouse collagen type II peptide $\mathrm{mCll}_{707-721}$ is CD1d restricted and activates CD4+TCR $\alpha \beta^{+}$NKT cells. (A) Significant proliferative response was observed after in vitro peptide stimulation of LNCs from mCll ${ }_{707-721}$-immunized mice (WT B10.Q). Controls are medium or control peptide $\mathrm{mCl}_{707-721}$. Proliferation index $(\mathrm{PI})$ was calculated by normalizing all $\mathrm{cpm}$ values to media control as 1 . (B) $\mathrm{PI}$ in response to $\mathrm{mCl}$ 707-721 in KO mice, all B10.Q background. Proliferation was significantly reduced compared with WT littermates in $T c r a b^{-/-}, C D 4^{-/-}$, and $C D 1 d^{-/-}$mice, indicating that the $\mathrm{mCll}_{707-721}$ peptide response depends on CD1d-restricted CD4+TCR $\alpha \beta^{+} \mathrm{T}$ cells, but not classical MHC I/II presentation. (C) $\mathrm{PI}$ in response to $\mathrm{mClI}_{707-721}$ in B10.Q LNCs. Blocking with anti-MHC II and anti-MHC I antibodies produced similar levels of PI compared with $\mathrm{mCll}_{707-721}$ with control antibody. PI was calculated by normalizing all cpm values to media control as 1 . (D) In vitro rechallenge response to $\mathrm{mCll}_{707-721}$, abrogated by anti-CD1 (1B1, $\left.10 \mu \mathrm{g} / \mathrm{ml}\right)$ or anti-NK1.1 (PK136, $\left.10 \mu \mathrm{g} / \mathrm{ml}\right)$, indicating that CD1d-dependent NKT cells were operative in the response. PI was calculated by normalizing all $\mathrm{cpm}$ values to media control as 1 . Data are mean $\pm \mathrm{SD}, n=6 .{ }^{* \star} P \leq 0.01 ;{ }^{* * *} P \leq 0.001$.

with the capacity to activate immune-suppressive NKT cells. The results have implications for antiinflammatory vaccines for human autoimmune disorders.

\section{Results}

Collagen peptide $m C I_{707-721}$ activates $C D 4^{+} T C R \alpha \beta^{+} T$ cells in an MHC I/II-independent manner. We immunized B10.Q mice with $\mathrm{mCII}_{707-721}$ and observed a strong and specific immune response, as measured by rechallenge of LN cells (LNCs) in vitro with $\mathrm{mCII}_{707-721}$ (Figure 1A). No response was induced in the absence of antigen (media) or by using a nonrelated peptide control, the mouse collagen type I $\alpha 1$ chain peptide $\mathrm{mCI}_{707-721}$, which shares high homology with $\mathrm{mCII}_{707-721}$. $\mathrm{mCI}_{707-721}$ was chosen as the negative control because this 15 -aa peptide is similar to
$\mathrm{mCII}_{707-721}$ in size and sequence, differing in only 4 aa positions. It also does not elicit any $\mathrm{T}$ cell proliferation. Purified protein derivative (PPD) has been used as a positive control (recall antigen) for accuracy of immunization and proliferation, given that it was used for all the in vivo assays. PPD reactivity showed a proliferation index (mean $\pm \mathrm{SD}$ ) of $12.8 \pm 2.1$. We also immunized $\mathrm{C} 57 \mathrm{BL} / 6$ mice $\left(\mathrm{H} 2^{\mathrm{b}}, 6\right.$ mice per group) with $\mathrm{mCII}_{707-721}$ and observed a similar immune response as with B10.Q (proliferation indexes: media $=1 ; \mathrm{mCI}_{707-721}=1.25 \pm 0.23 ; \mathrm{mCII}_{707-721}=$ $3.68 \pm 0.32, P \leq 0.001$ versus each negative and positive control; $\mathrm{PPD}=12.78 \pm 2.09)$. This indicates that the $\mathrm{mCII}_{707-721}$-reactive response is not strain specific. However, to control for possible strain-specific effects, the remainder of the study utilized only mice of B10.Q background. 
A

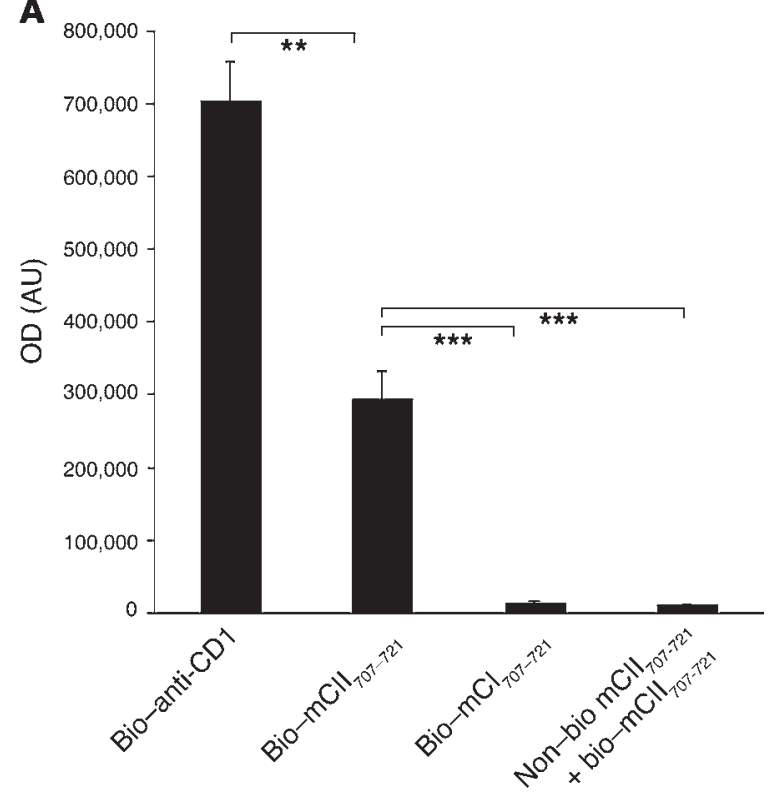

C

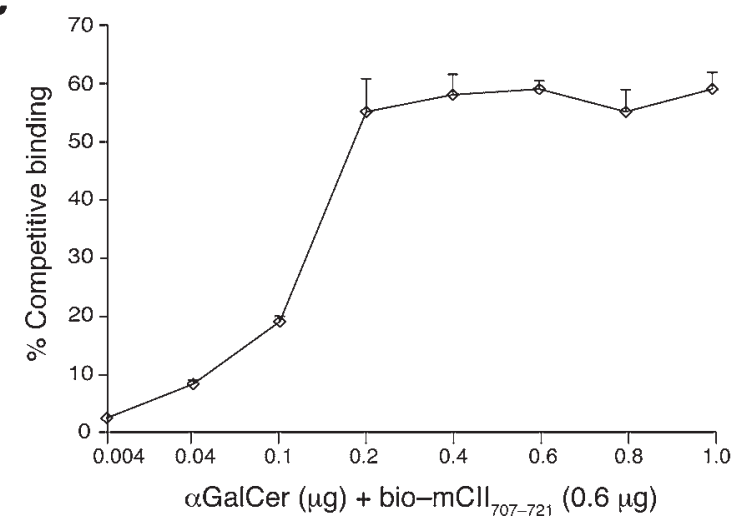

B

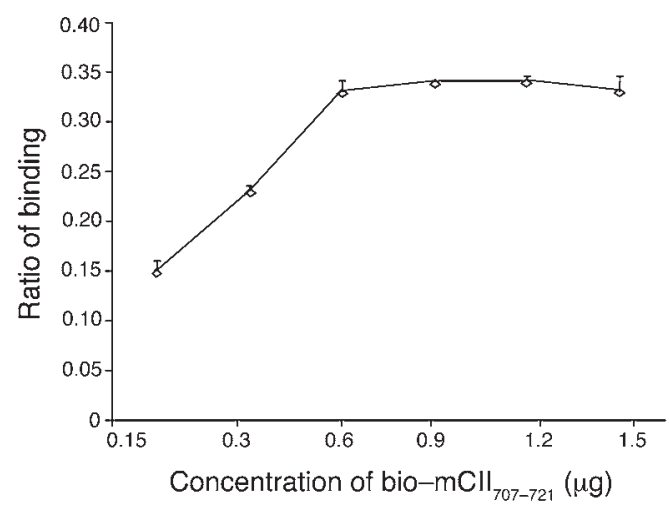

\section{Figure 2}

mCll $_{707-721}$ binds CD1d. (A) The binding capacity of $\mathrm{mCll}_{707-721}$ to CD1d was determined using ELISA plates coated with CD1d-Ig dimer, with biotin-labeled anti-CD1d (bio-anti-CD1) (positive control), biotin-labeled mCll ${ }_{707-721}$ peptide, or biotin-labeled mCl $\mathrm{m}_{707-721}$ (negative control). Excess nonlabeled $\mathrm{mCl}_{707-721}$ peptide with biotin-labeled $\mathrm{mCll}_{707-721}$ peptide was used for competitive binding. Significant differences were seen in wells with biotin-labeled $\mathrm{mCll}_{707-721}$ peptide compared with negative control or excess nonlabeled peptide. (B) mCll $\mathrm{m}_{707-721}$ binding to CD1d was concentration dependent, with a maximum binding capacity of $0.6 \mu \mathrm{g} / \mathrm{ml}$. Ratio of binding is the fluorometer OD of the sample divided by the positive control OD. (C) $\alpha$ GalCer and biotinylated-labeled $\mathrm{mCll}_{707-721}$ peptide compete for binding to CD1d. Biotinylated-labeled mCll $707-721$ peptide binding to CD1d is considered as $100 \%$ binding. Data are mean $\pm \mathrm{SD}, n=3-4$. ${ }^{\star *} P \leq 0.01 ;{ }^{* \star *} P \leq 0.001$.

We characterized the $\mathrm{T}$ cell response toward the $\mathrm{mCII}_{707-721}$ peptide, using $\mathrm{KO}$ mice of genotypes $\mathrm{MHC} \mathrm{II-/,}^{-} \mathrm{TAP1}^{-/-}, \mathrm{CD} 1 \mathrm{~d}^{-/}$, $\mathrm{Tcrab}^{-/}, \mathrm{Tcrgd}^{-/}, \mathrm{CD} 4^{-/}$, and $\mathrm{CD} 8^{-/}$, all backcrossed to the same genetic background, B10.Q. These were immunized and LNCs were rechallenged with or without antigens in vitro. Proliferative response to $\mathrm{mCII}_{707-721}$ required TCR $\alpha \beta$ expression, $\mathrm{CD} 4^{+} \mathrm{T}$ cells, and CD1d, but was not dependent on TCR $\gamma \delta$ expression or CD8 ${ }^{+}$ $\mathrm{T}$ cells (Figure 1B). No difference in proliferation was observed among the various KO mice and WT B10.Q mice in response to control peptides used in the assay (data not shown).

We investigated potential antigen-presenting molecules for $\mathrm{mCII}_{707-721}$ using $\mathrm{MHC} \mathrm{II^{-/- }}$ mice and TAP-deficient mice (TAP1 ${ }^{-/-}$), which lack transporter associated with antigen processing, important for presentation of MHC I-restricted peptides. By utilizing these mice (Figure 1B), as well as monoclonal antibodies to block
MHC class I and II (Figure 1C), sustained proliferation to $\mathrm{mCII}_{707-721}$ was observed. These data indicate that the $\mathrm{mCII}_{707-721}$ response was neither MHC II- nor MHC I-restricted. An MHC II-binding assay also verified that the $\mathrm{mCII}_{707-721}$ peptide did not bind to $\mathrm{H}-2 \mathrm{q}$ (data not shown). These results demonstrate that the $\mathrm{T}$ cell response to $\mathrm{mCII}_{707-721}$ was dependent on CD4 and TCR $\alpha \beta$, but unexpectedly, did not involve MHC I or II presentation.

$m C I I_{707-721}$ binds to CD1d and activates NKT cells. Mice were immunized with $\mathrm{mCII}_{707-721}$, and recall antigen reactivity of LNCs or splenocytes was measured 10-13 days after immunization. As shown in Figure 1B and Figure 1D, the proliferative response to $\mathrm{mCII}_{707-721}$ was essentially completely diminished when mice genetically lacking CD1d-dependent NKT cells (CD1 $d^{-/-}$mice) were investigated or monoclonal antibodies to CD1d or NK1.1 were added to cultures prior to restimulation with $\mathrm{mCII}_{707-721}$. 

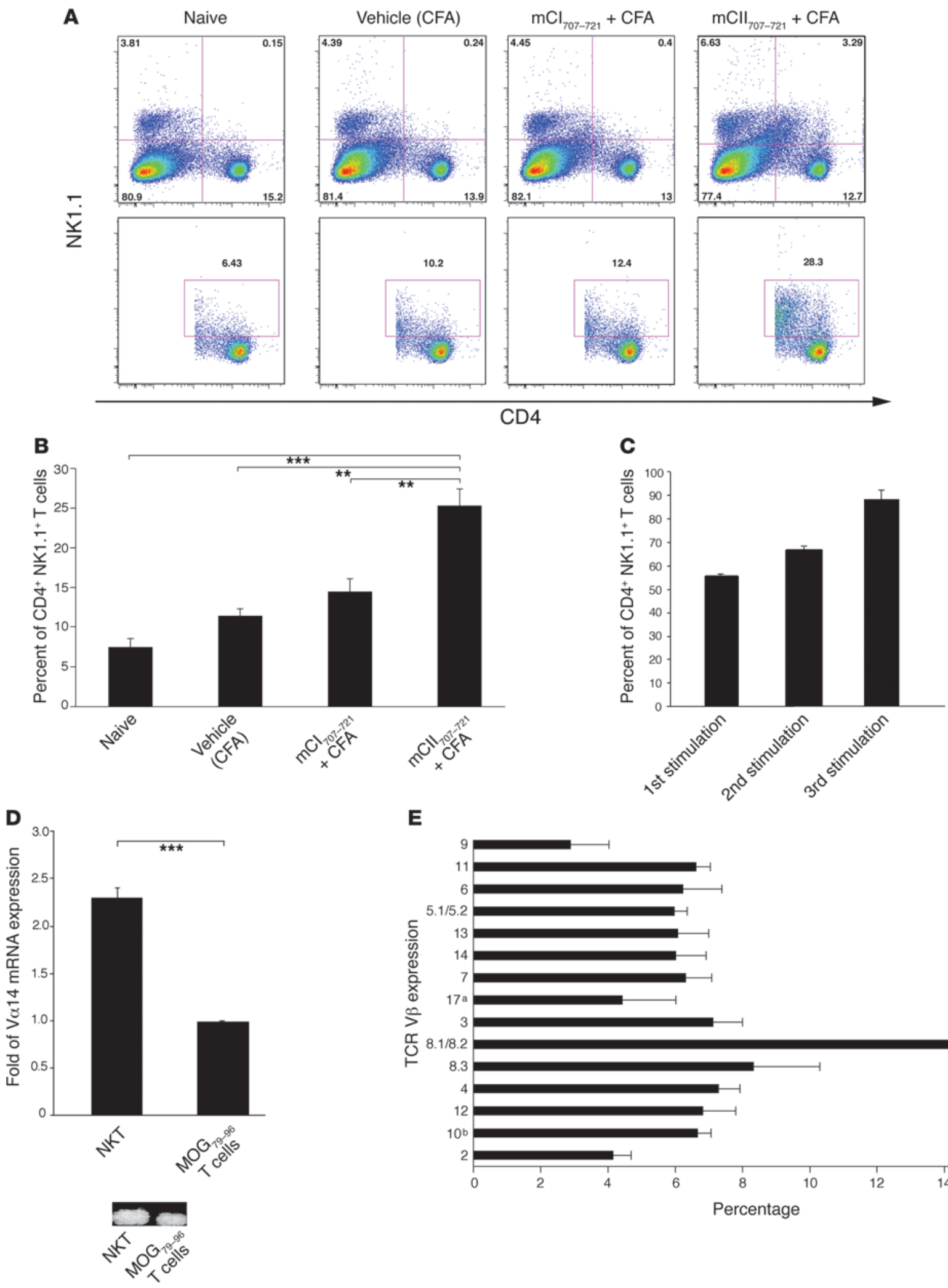

E

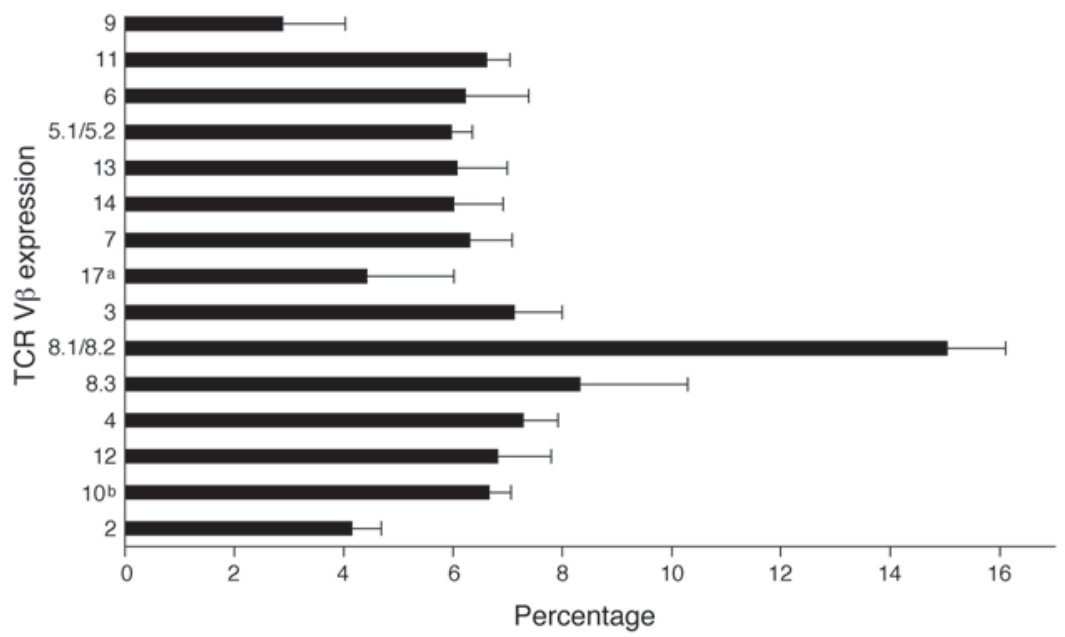




\section{Figure 3}

$\mathrm{mCll}_{707-721}$ induces NKT cell expansion. (A and B) Splenocytes were taken from naive WT (B10.Q) mice and in vivo CFA-, $\mathrm{mCl}_{707-721-}$, and $\mathrm{mCll}_{707-721}$-treated mice. Single-cell suspensions were made and then stimulated with $100 \mu \mathrm{g} / \mathrm{ml} \mathrm{mCll}{ }_{707-721}$ for 48 hours. $n=3$ mice per group. (A) A representative FACS staining shows total gated lymphocytes (upper row) and gated CD4+NK1.1+ NKT cells (lower row). (B) Percentage of CD4+NK1.1+ NKT cells from indicated groups. Data are mean \pm SD, $n=3$. ${ }^{* \star} P \leq 0.01 ;{ }^{* * \star} P \leq 0.001$. (C) Proportion of NK1.1 $1^{+}$T cells in cell line during the first stimulation of LNCs (57\%), and after $2(65 \%)$ and 3 $(88 \%)$ in vitro stimulation cycles with $\mathrm{mCll}_{707-721}$. NK1.1+ $\mathrm{T}$ cells enriched after each stimulation, indicating response and proliferation after $\mathrm{mCll}_{707-721}$ exposure. Data are mean \pm SD. $n=3$. (D) $\mathrm{mCll}_{707-721}-$ specific cell line characterized for TCR usage after 3 stimulation cycles with a significantly higher proportion of $\mathrm{V} \alpha 14-\mathrm{J} \alpha 18$ by real-time qPCR com-

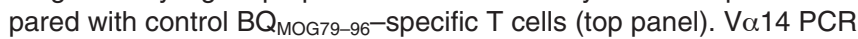
product in agarose gel is shown (bottom panel). Data are mean \pm SD. $n=3$. ${ }^{* \star *} P \leq 0.001$. (E) Splenocytes were taken from $\mathrm{mCll}_{707-721}$-immunized mice treated with $100 \mu \mathrm{g} / \mathrm{ml} \mathrm{mCll} \mathrm{m}_{707-721}$ for 48 hours. FACS staining shows TCR $\mathrm{V} \beta$ usage. Percentages were computed relative to the sum of all of the 15 chains. Data are mean $\pm \mathrm{SD}, n=3$.

No effect on $\mathrm{mCI}_{707-721}$ or PPD was observed (data not shown). Similarly, depletion of NK1.1 $1^{+}$cells, or antibody blocking of CD1d in vivo prior to subsequent immunization with $\mathrm{mCII}_{707-721}$, resulted in reduced proliferative response to $\mathrm{mCII}_{707-721}$ (data not shown). Thus, the response to $\mathrm{mCII}_{707-721}$ was confirmed to be CD1d restricted.

The binding capacity of $\mathrm{CD} 1 \mathrm{~d}$ for $\mathrm{mCII}_{707-721}$ was determined using recombinant soluble dimeric mouse CD1d immunoglobulin and biotinylated $\mathrm{mCII}_{707-721}$. Significant binding of biotinylated $\mathrm{mCII}_{707-721}$ to CD1d was observed, while no binding of the negative control, biotinylated $\mathrm{mCI}_{707-721}$, was detected. Excess nonbiotinylated $\mathrm{mCII}_{707-721}$ peptide effectively competed for binding of biotinylated $\mathrm{mCII}_{707-721}$ to $\mathrm{CD} 1 \mathrm{~d}$ (Figure $2 \mathrm{~A}$ ). Figure $2 \mathrm{~B}$ shows that the interaction was dose dependent and saturable. Using $\alpha$ GalCer with biotinylated $\mathrm{mCII}_{707-721}$ revealed that at certain concentrations it competes for the binding to CD1d, indicating partial competition for the binding site (Figure 2C). PBS (non-CD1d-Ig dimer) is used for negative control.

$m C I I_{707-721}$ activates a beterogeneous NKT cell population. To investigate the frequency of NKT cell expansion in response to $\mathrm{mCII}_{707-721}$, WT B10.Q mice were treated in vivo with $\mathrm{mCII}_{707-721}$ and CFA and 13 days later, splenocytes were analyzed. $\mathrm{mCII}_{707-721}$ is capable of significantly inducing NKT cell expansion (gated on CD4 ${ }^{+} \mathrm{NK} 1.1^{+}$ $\mathrm{T}$ cells) compared with all other control groups, namely vehicletreated (CFA), $\mathrm{mCI}_{707-721}$, and naive mice (Figure 3, $\mathrm{A}$ and $\mathrm{B}$ ).

To further characterize the $\mathrm{mCII}_{707-721}$-responding $\mathrm{T}$ cells, a peptide-specific cell line was established by subjecting LNCs from mice immunized with $\mathrm{mCII}_{707-721}$ to different cycles of restimulation and resting. Expression of the NK1.1 marker was confirmed after each round of antigenic stimulation. Figure $3 \mathrm{C}$ shows that $57 \%$ of the $\mathrm{CD}^{+} \mathrm{mCII}_{707-721^{-}}$-specific $\mathrm{T}$ cells in the primary cell line were NK1.1 $1^{+}$T cells. This percentage increased to $65 \%$ after the second stimulation and to $88 \%$ after the third, indicating enrichment of NKT cells upon antigenic stimulation.

NKT cells can utilize a diverse combination of $\mathrm{V} \alpha$ and $\mathrm{V} \beta$ chains, with evidence suggesting that any of the V $\beta$ chains can pair with the Vo14 invariant chain (14). The TCR V $\alpha$ usage of the $\mathrm{mCII}_{707-721}$-specific NKT line was characterized by real-time quantitative PCR (qPCR) and FACS. A conventional T cell line specific to the CNS self-antigenic peptide myelin oligodendrocyte glycoprotein 79-96 (MOG ${ }_{79-96}$ ) was included for comparison. The

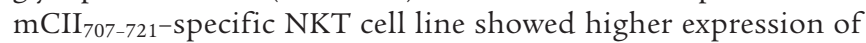
V $\alpha 14-J \alpha 18$ than the conventional T cell line by real-time quantitative PCR (qPCR) (Figure 3D). Using a panel of V $\beta$ TCR antibodies to stain $\mathrm{mCII}_{707-721^{-}}$specific NKT cells showed that these cells utilize polyclonal and diverse $V \beta$ chains (Figure 3E). Although some skewing toward usage of $\mathrm{V} \beta 8.2$ is seen, $\mathrm{mCII}_{707-721}$ reactivity is heterogeneous, not clonal.

Activation of $m \mathrm{CII}_{707-721}$-reactive NKT cells requires TCR and costimulatory signaling. To examine TCR signaling in the $\mathrm{mCII}_{707-721-}$-specific response, we investigated ZAP-70 phosphorylation in the

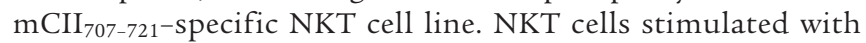
$\mathrm{mCII}_{707-721}$ expressed phosphorylated ZAP-70 on the cell membrane, indicating TCR engagement and signaling (Figure 4A). Furthermore, blocking CD1d by adding a neutralizing antibody to the culture medium completely inhibited the appearance of phosphorylated ZAP-70 on the cell surface. Thus, interaction among $\mathrm{CD} 1 \mathrm{~d}, \mathrm{mCII}_{707-721}$, and TCR is operative in the activation

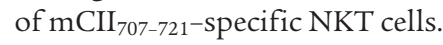

The requirement for costimulatory signals in the activation of $\mathrm{mCII}_{707-721-s p e c i f i c}$ NKT cells was studied using antibodies or fusion proteins to block the B7- and CD40-dependent pathways in peptide-stimulated $\mathrm{LNC}$ cultures from $\mathrm{mCII}_{707-721^{-}}$ immunized mice. Blocking either the CD40/CD40L or the $\mathrm{B} 7 / \mathrm{CD} 28$ pathways led to significant inhibition of the proliferative response (Figure 4B) and showed that B7.1, but not B7.2, was the crucial ligand for CD28 on the NKT cells. The data support the interpretation that B7.1-CD28 and CD40-CD40L, in addition to CD1d-TCR ligation, are the necessary signals for $\mathrm{mCII}_{707-721}$-induced NKT cell activation.

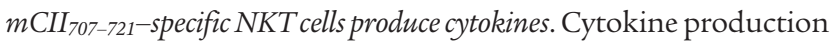
by the $\mathrm{mCII}_{707-721}$-specific NKT cells was measured by ELISA for IFN- $\gamma$, IL-2, IL-4, IL-10, TGF- $\beta 1$, and TNF- $\alpha$ in peptide-stimulated LNC cultures from mCII ${ }_{707-721}$-immunized mice. TGF- $\beta 1$, IFN- $\gamma$, and IL-4 production was significantly increased compared with cells stimulated with the negative control media and $\mathrm{mCI}_{707-721}$ (Figure 5A). IL-2 and IL-10 production was undetectable (data not shown). Interestingly, TNF- $\alpha$ production was significantly reduced upon $\mathrm{mCII}_{707-721}$-specific NKT cell activation (Figure 5B). The kinetics of cytokine production resembled those of conventional $\mathrm{T}$ cells, i.e., peaking at 72 hours after restimulation in vitro and showing no early burst of cytokines (data not shown).

To investigate whether NKT cells are the direct source of cytokine production, we treated WT B10.Q mice with $\mathrm{mCII}_{707-721}$ plus CFA in vivo. As control groups, mice were treated with $\mathrm{mCI}_{707-721}$ plus CFA; an additional group received only vehicle (CFA), and finally a group of mice did not receive any treatment (naive). Splenocytes were dissected and single-cell suspensions treated in vitro with $\mathrm{mCII}_{707-721}$ for 48 hours. Cells were then stained for intracellular cytokines and analyzed using FACS. As shown in Figure 6, $\mathrm{mCII}_{707-721^{-}}$ specific NKT cells are capable of intracellular production of TGF- $\beta 1$, IFN- $\gamma$, IL-4, and TNF- $\alpha$. However, the levels of TNF- $\alpha$ intracellularly (Figure 5B) exhibited a trend similar to the levels seen as assessed by ELISA (Figure 7D), i.e., reduction in the in vivo

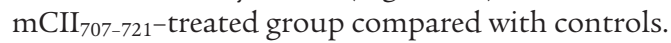

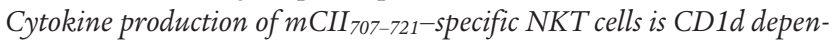
dent. Splenocytes from similarly treated B10.Q WT and CD1 $d^{-/-}$ mice were analyzed for the production of cytokines in response to $\mathrm{mCII}_{707-721}$. As depicted in Figure 7, A-C, only WT mice that 
A

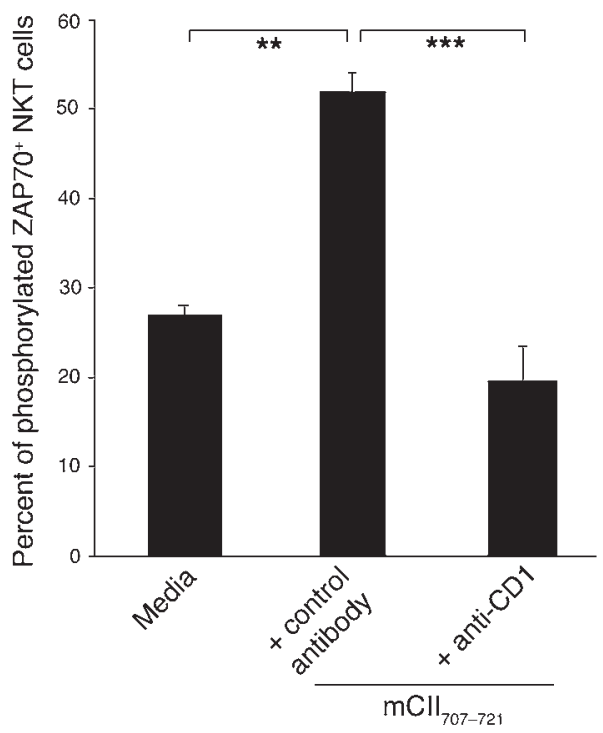

B

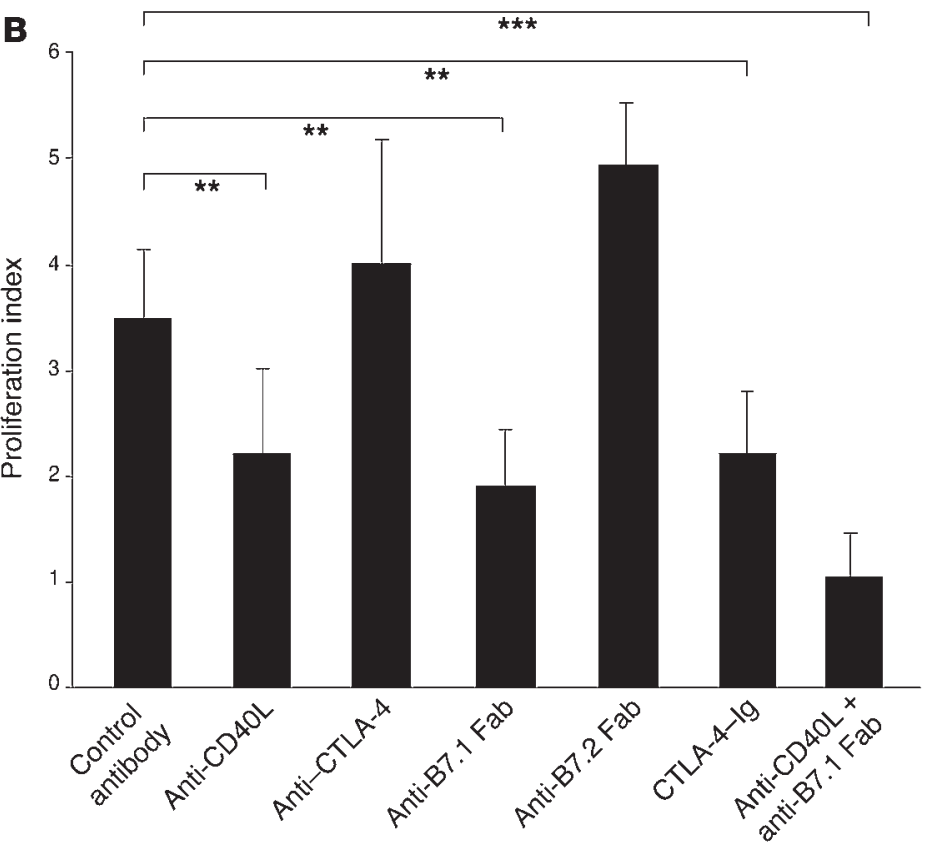

Figure 4

$\mathrm{mCll}_{707-721}-$ specific NKT cell activation engages TCR and requires costimulation. (A) Activation of mCll ${ }_{707-721}-$ specific NKT cells operated through TCR signaling. Percentage of phosphorylated ZAP70-positive cells in NK1.1+ T cells by FACS shows a significant increase over nonstimulated cells upon $\mathrm{mCl}_{707-721}$ stimulation in vitro, with abrogation by blocking anti-CD1 (1B1, $\left.10 \mu \mathrm{g} / \mathrm{ml}\right)$. (B) Costimulatory signals for proliferation after in vitro stimulation of $\mathrm{LNCs}$ from $\mathrm{mCll}_{707-721}$-immunized mice. Blocking with antibodies to costimulatory proteins significantly reduced proliferation. Data are mean $\pm \mathrm{SD}, n=4 .{ }^{* \star} P \leq 0.01 ;{ }^{* * *} P \leq 0.001$.

were treated in vivo with $\mathrm{mCII}_{707-721}$ showed significant capacity to produce TGF- $\beta 1$, IFN- $\gamma$, and IL- 4 , as measured by ELISA. Moreover, $\mathrm{mCII}_{707-721}$-specific TGF- $\beta 1$, IFN- $\gamma$, and IL-4 production was significantly reduced in $C D 1 d^{-/-}$compared with WT mice, though interestingly, a significantly lower TNF- $\alpha$ production was observed (Figure 7D).

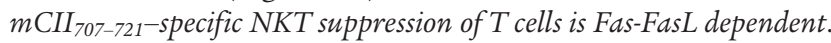
In vitro suppression of $\mathrm{T}$ cells was investigated by activating syngeneic splenocytes with plate-bound anti-CD3 (here referred to as responder cells), which were then cocultured with the $\mathrm{mCII}_{707-721}$ specific NKT cell line. Responder cells proliferated vigorously as indicated by a high proliferation index (Figure 8). However,

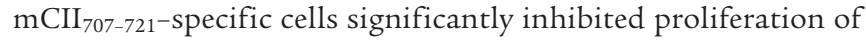
anti-CD3-stimulated responder $\mathrm{T}$ cells, compared with the control conventional $\mathrm{MOG}_{79-96} \mathrm{~T}$ cell line. Since the $\mathrm{mCII}_{707-721}$-specific NKT cells produced TGF- $\beta 1$, IFN- $\gamma$, and IL-4 upon activation, we assessed the role of these cytokines in $\mathrm{T}$ cell suppression. To block these cytokines, neutralizing antibodies were added to $\mathrm{mCII}_{707-721^{-}}$
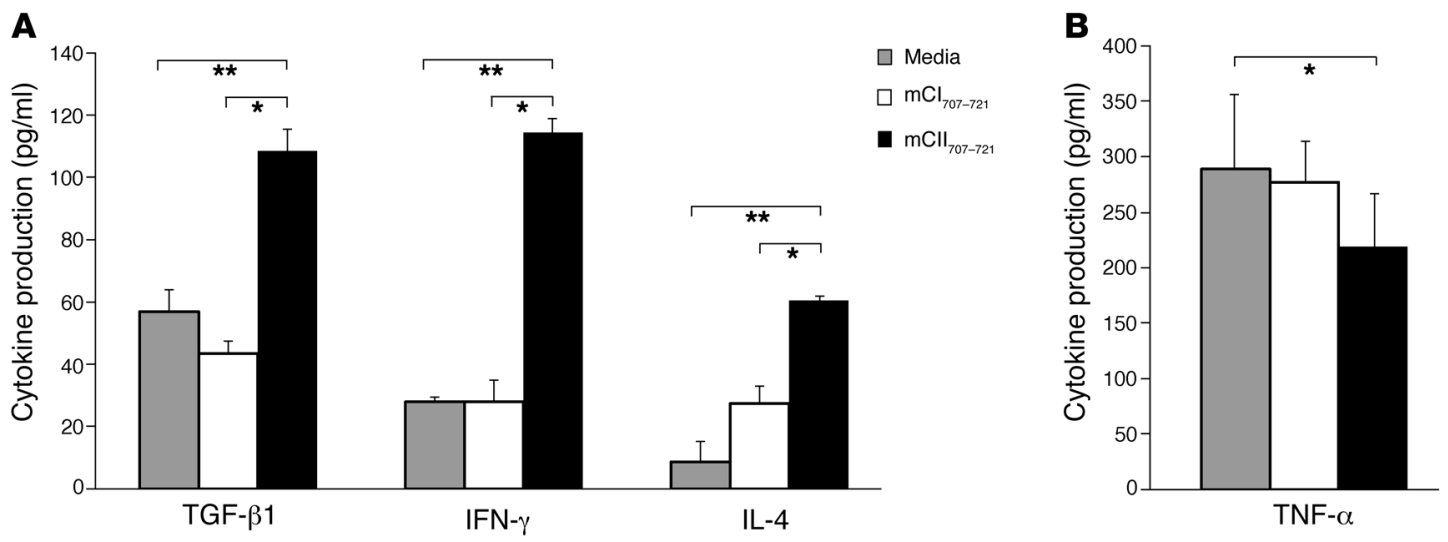

Figure 5

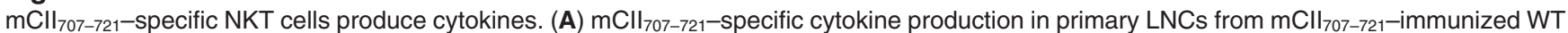
mice measured by ELISA. Significantly elevated levels of TGF- $\beta 1$, IFN- $\gamma$, and IL-4 $(n=3)$ in response to mCll m $_{707-721}$ are seen, but $(B)$ TNF- $\alpha$ levels were lowered. Data are mean $\pm \mathrm{SD}, n=6 .{ }^{*} P \leq 0.05 ;{ }^{* *} P \leq 0.01$. 
A

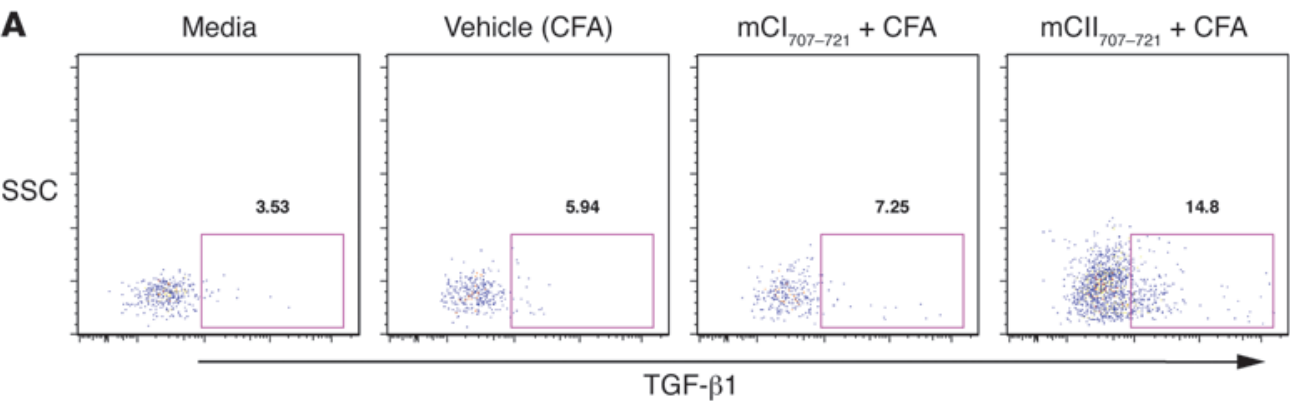

B

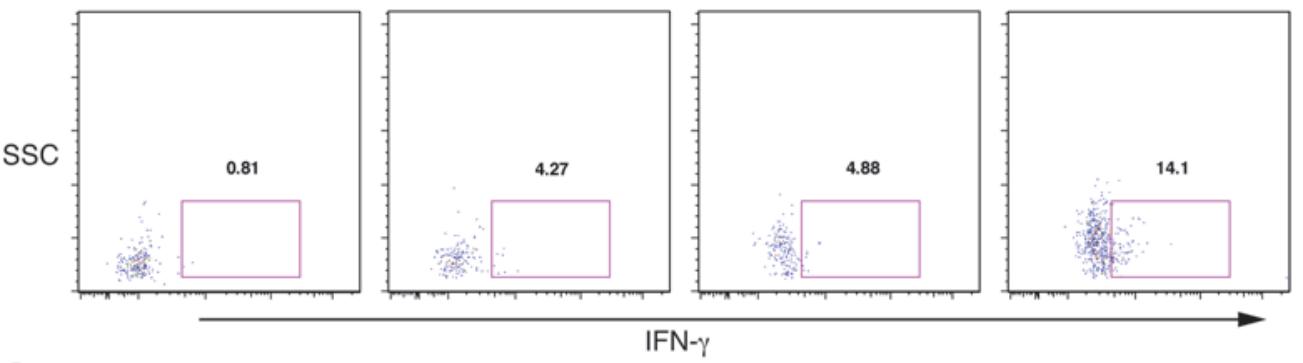

C

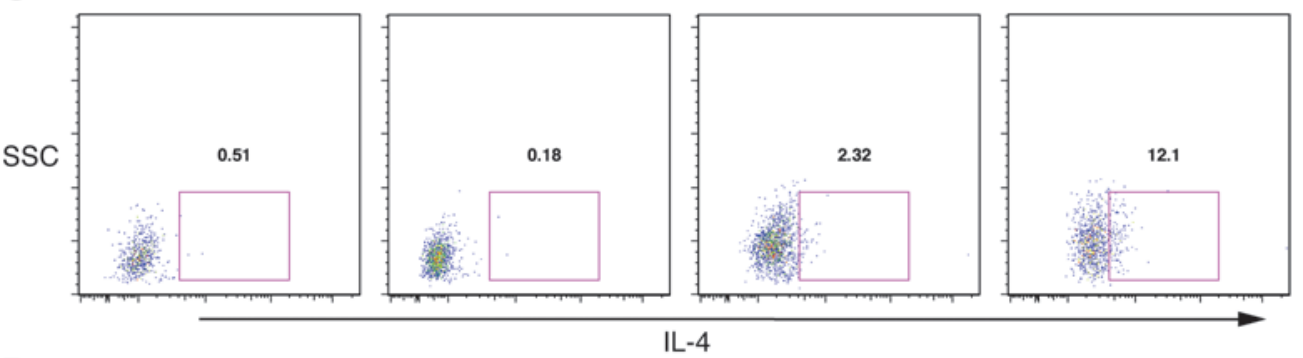

D

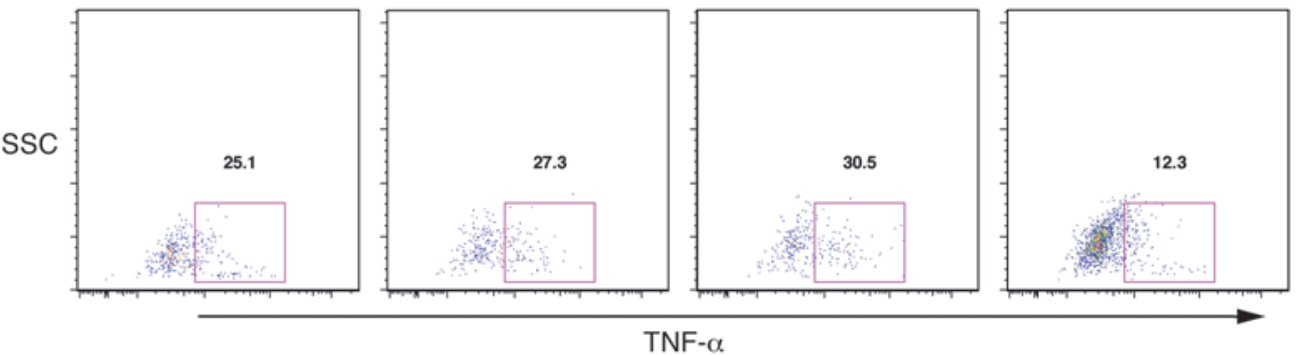

\section{Figure 6}

mCll ${ }_{707-721}-$ specific NKT cells produce cytokines intracellularly. Intracellular staining indicates that $\mathrm{mCll}_{707-721}$ induces TGF- $\beta 1$, IFN- $\gamma$, and IL-4 production $(\mathbf{A}-\mathbf{C})$, but not increased TNF- $\alpha$ (D). (A-D) Splenocytes were taken from $\mathrm{mCl}_{707-721}-$ and $\mathrm{mCll}_{707-721-}$ immunized mice, then stimulated with $\mathrm{mCll}_{707-721}$ for 48 hours. Anti-CD3 $(10 \mu \mathrm{g} / \mathrm{ml})$ and antiCD28 $(2 \mu \mathrm{g} / \mathrm{ml})$ with brefeldin A were added to cell cultures for 5 hours before staining. FACS profile shows intracellular staining of TGF- $\beta 1$, IFN- $\gamma$, IL- 4 , and TNF- $\alpha$. Cells were gated on CD4+NK1.1+ cells. specific NKT cell cultures prior to coculture with anti-CD3-activated splenocytes. The neutralizing antibodies did not affect the significant decrease in responder $\mathrm{T}$ cell proliferation (Figure 8A), indicating that the suppressive effect of $\mathrm{mCII}_{707-721}$-specific NKT cells was independent of their cytokine production.

Since these soluble cytokines seem to exert no major effects in the context of $\mathrm{mCII}_{707-721}$-specific NKT cell suppression, we investigated to determine whether cell-cell contact was required. As depicted in Figure 8B, the suppressive function of the $\mathrm{mCII}_{707-721^{-}}$ specific NKT cells was dependent on cell-cell contact, since separating direct cell-cell interaction using a Transwell system abrogated their suppressive effect.

We investigated whether $\mathrm{mCII}_{707-721}$-specific NKT cells could induce apoptosis, as measured by annexin V staining of anti-CD3activated responder cells. Upon coculture, $\mathrm{mCII}_{707-721-}$ specific NKT cells significantly induced apoptosis of anti-CD3-activated responder cells (Figure 8C). As Fas-FasL is one of most common mechanisms for induction of apoptosis (15), we used FasL-blocking antibody to determine whether Fas-FasL is involved in apoptosis induction. Cell death induced by $\mathrm{mCII}_{707-721}$-specific NKT cells was Fas-FasL dependent, since adding FasL-blocking antibody to the cultures inhibited apoptosis (Figure 8C). To confirm this result, we purified $\mathrm{mCII}_{707-721}$-specific NKT cells from $\mathrm{mCII}_{707-721}$-immunized Fas receptor-deficient mice ( $l p r$ mice). Anti-CD3-activated responder cells were cocultured with $\mathrm{mCII}_{707-721-\text { specific } \mathrm{NKT}}$ cells from $l p r$ or WT mice, and cell death quantified as 7-aminoactinomycin D-positive (7AAD-positive) cells by FACS. Figure 8D shows that the cytotoxic function of $\mathrm{mCII}_{707-721}$-specific NKT cells was Fas-FasL dependent.

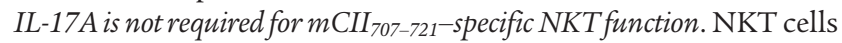
are reported to produce IL-17 (16), so we stained splenocytes from

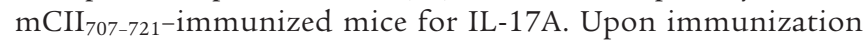
with $\mathrm{mCII}_{707-721}, 37.3 \%$ of NKT cells produced IL-17A (Figure 9A). However, IL-17A did not appear to play a role in the suppressive 
A
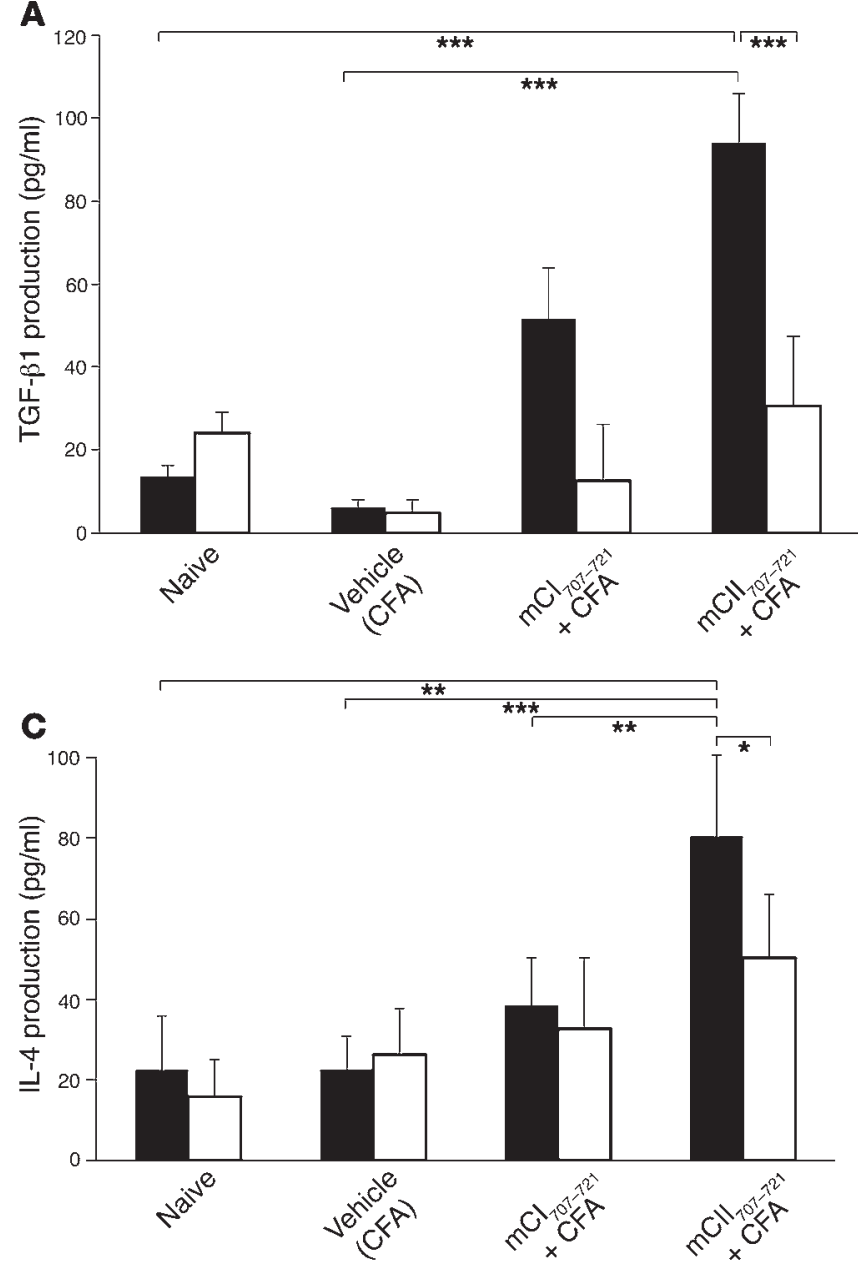

B

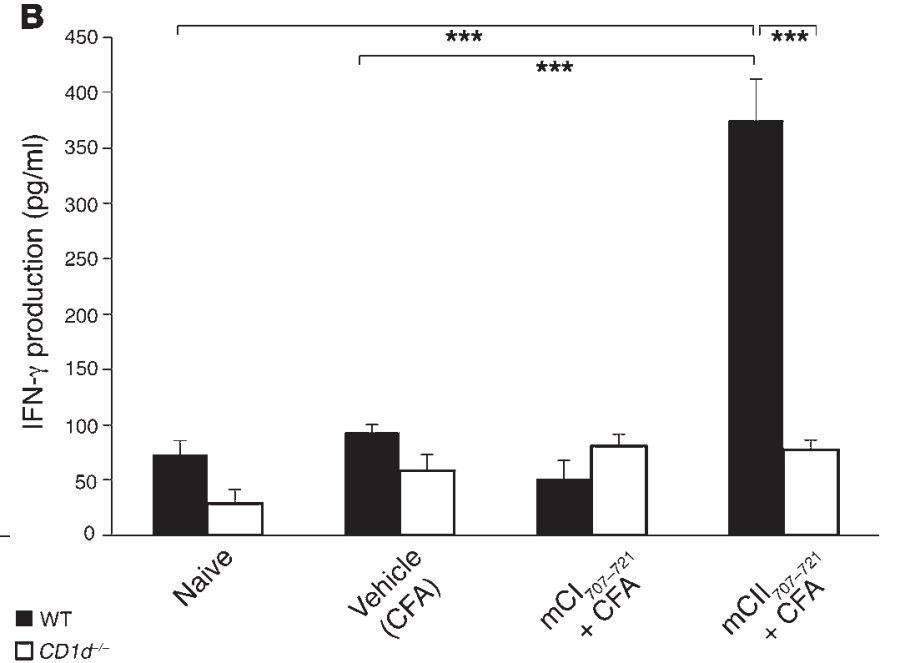

D

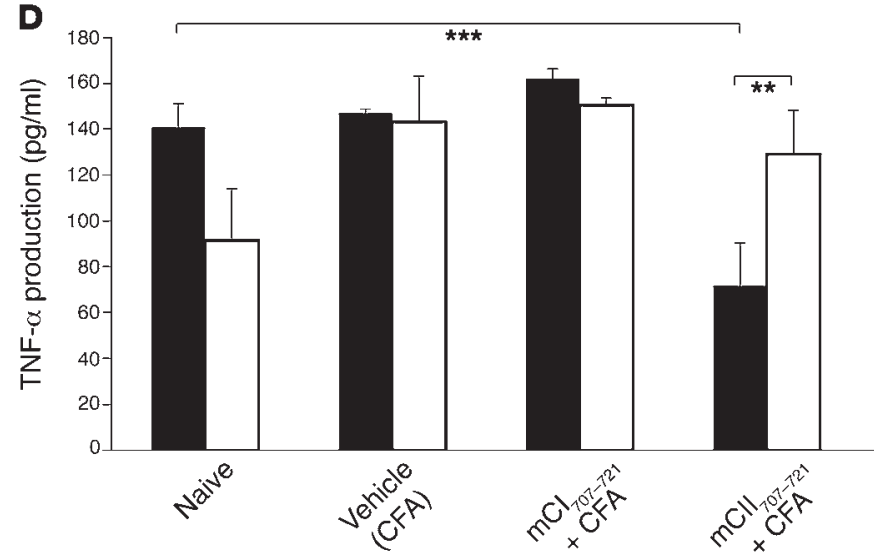

Figure 7

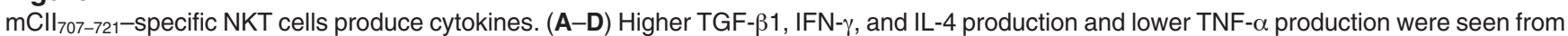

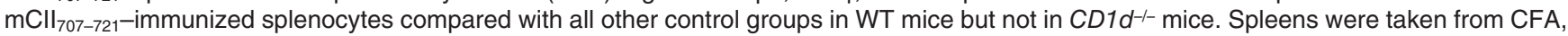
$\mathrm{mCl}_{707-721-}$, and $\mathrm{mCl}_{707-721}$-immunized mice, then treated with $\mathrm{mCll}_{707-721}$ for 48 hours. Supernatants were taken for ELISAs of TGF- $\beta 1$, IFN- $\gamma$, $\mathrm{IL}-4$, and TNF- $\alpha$. Data are mean $\pm \mathrm{SD}, n=5$ mice per group. ${ }^{\star} P \leq 0.05 ;{ }^{* \star} P \leq 0.01 ;{ }^{* \star} P \leq 0.001$

function of these cells. CFSE-labeled $\mathrm{CD}^{+} \mathrm{T}$ cells were cocultured with $\mathrm{mCII}_{707-721^{-}}$specific NKT cells in an anti-CD3-coated plate, with or without neutralizing IL-17A antibody. After 48 hours, cell death was analyzed with 7AAD staining on gated $\mathrm{CD} 4^{+} \mathrm{T}$ cells. The percentage of $7 \mathrm{AAD}^{+} \mathrm{T}$ cells was similar with or without IL-17A blocking, suggesting that IL-17A was not involved in $\mathrm{mCII}_{707-721^{-}}$ specific NKT cells' suppressive function (Figure 9B).

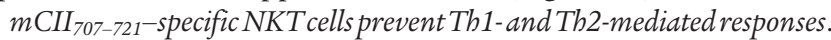
The in vivo suppressive capacity of $\mathrm{mCII}_{707-721-}$-specific NKT cells was investigated using B10.Q mice vaccinated with $\mathrm{mCII}_{707-721}$ or the negative control peptide $\mathrm{mCI}_{707-721}$, prior to induction of a delayed-type hypersensitivity (DTH) reaction. Mice vaccinated with $\mathrm{mCII}_{707-721}$ developed significantly less inflammation than the control group (Figure 10, A and B). Moreover, the antiinflammatory effect of $\mathrm{mCII}_{707-721}$ vaccination was dependent upon activation of CD1d-restricted $\mathrm{mCII}_{707-721^{-}}$specific NKT cells, since lack of this population in $C D 1 d^{-/-}$mice resulted in significant abrogation of the antiinflammatory effect (Figure 10C). These results support the in vitro findings that $\mathrm{CD} 1 \mathrm{~d}$-restricted $\mathrm{mCII}_{707-721}$-specific $\mathrm{NKT}$ cells suppress $\mathrm{T}$ cell activation and hence inhibit Th1-polarized DTH inflammation.

We next studied the effect of CD1d-restricted mCII $_{707-721} \mathrm{NKT}$ cells on the Th2-mediated immune response. Mice were vaccinated as above and then to provoke a Th2 response were injected with OVA emulsified in alum. Interestingly, a downregulated Th2 response was observed in the $\mathrm{mCII}_{707-721-\text { vaccinated group com- }}$ pared with control. A significant decrease in IL-4, IL-5, and IL-13 production was detected in bronchoalveolar lavage fluid (BALF) after OVA rechallenge in WT mice. Moreover, we observed that vaccination with $\mathrm{mCII}_{707-721}$ repressed $\mathrm{IgE}$ production in BALF of WT mice. Furthermore, mCII $_{707-721-}$-specific NKT cell activation and the antiinflammatory effects of such activation were determined to be CD1d restricted, as $C D 1 d^{-/-}$mice lacked such capacity (Figure 11). Taken together, the observations show that the $\mathrm{mCII}_{707-721-}$-specific CD1d-restricted NKT cells are involved in immune regulation of both Th1-mediated cellular responses and Th2-mediated humoral immune responses. 
A

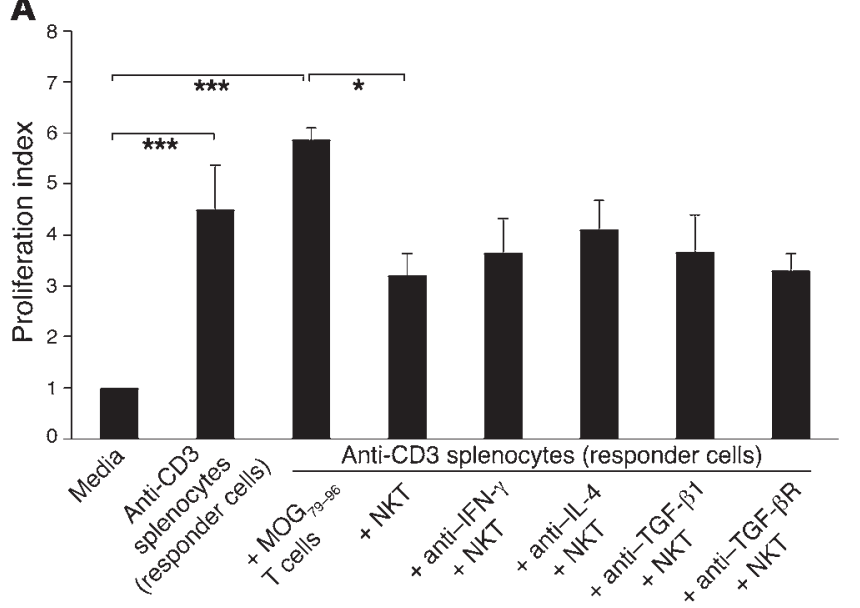

B

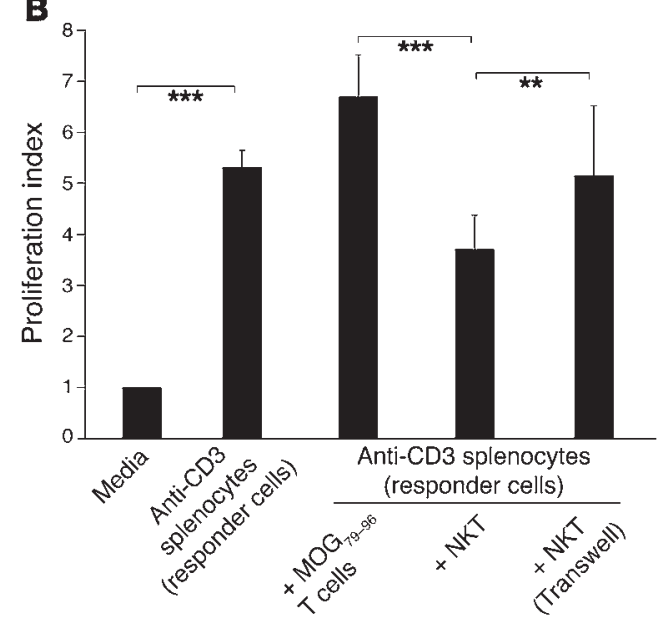

D

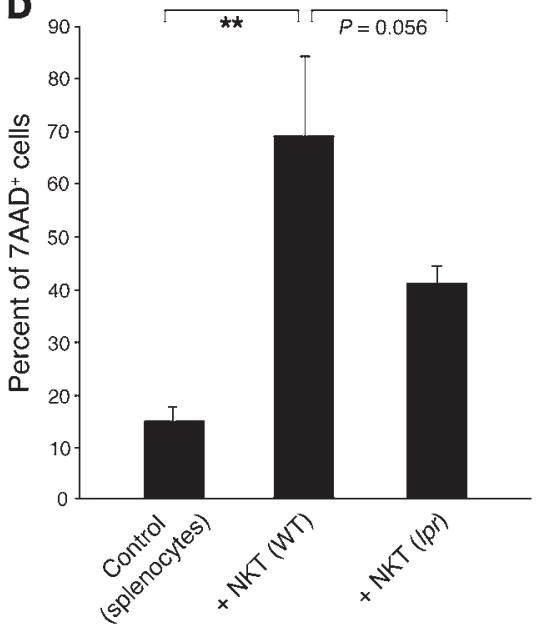

\section{Figure 8}

mCll ${ }_{707-721}-$ specific NKT cells have a suppressive function. (A and B) Suppressor assay was performed using in vitro-stimulated anti-CD3 splenocytes (responder cells) from B10.Q mice, cocultured for 64 hours with either mCll ${ }_{707-721}-$ specific NKT cell line or B10.Q-restricted MOG M9-96- $^{-}$ specific $T$ cell line (control) at a 1:1 ratio. Proliferation index was calculated by normalizing all cpm values to media control as 1 . (A) Blocking IFN- $\gamma$, IL-4, TGF- $\beta 1$, and TGF- $\beta$ receptor with antibodies $(20 \mu \mathrm{g} / \mathrm{ml})$ had no effect on NKT cell suppression compared with isotype-matched controls; therefore suppression did not operate through cytokine release from $\mathrm{mCll}_{707-721}$-specific NKT cells. Data are mean $\pm \mathrm{SD}, n=3$. ${ }^{*} P \leq 0.05$; ${ }^{* * \star} P \leq 0.001$. (B) Significantly reduced proliferation of anti-CD3-stimulated responder cells was observed when cultured with the mCl${ }_{707-721}-\mathrm{specific}$ NKT cells (with or without Transwell system) compared with control cells. Proliferation of the responder cells was restored when a Transwell system inhibited cell-cell contact. Data are mean $\pm \mathrm{SD}, n=2-3 .{ }^{* *} P \leq 0.01 ;{ }^{* * *} P \leq 0.001$. (C) Cell death by annexin $\mathrm{V}^{+}$FACS analysis of cocultured splenocytes (CFSE labeled), showing that the $\mathrm{mCl}_{707-721}-$ specific NKT cell line induced significantly elevated cell death levels compared with the control cells. Anti-FasL $(20 \mu \mathrm{g} / \mathrm{ml})$ before coculturing revealed that splenocyte killing was mediated by FasL interaction. Data are mean $\pm \mathrm{SD}, n=3$. ${ }^{\star \star} P \leq 0.01$. (D) Splenocytes (CFSE labeled) from WT mice stimulated with plate-bound anti-CD3 and cocultured for 48 hours with NKT cells purified from $\mathrm{mCll}_{707-721}$-immunized WT mice or $/ p r$ mice. Cell death was determined by 7AAD staining. Data are mean $\pm \mathrm{SD}, n=10$ mice per group. ${ }^{* \star} P \leq 0.01$.

Activation of $m$ CII $I_{707-721}-$ specific NKT cells ameliorates CIA. The $\mathrm{mCII}_{707-721}$ peptide is a major epitope in mouse collagen type II, so $\mathrm{mCII}_{707-721^{-}}$specific cells might be crucial for regulating CIA. To test our hypothesis, B10.Q mice were vaccinated with either $\mathrm{mCII}_{707-721}$ or control peptide 10 days prior to CIA induction. We found that $\mathrm{mCII}_{707-721}$ vaccination ameliorated the severity of arthritis compared with the control (Figure 12A). The incidence in the $\mathrm{mCII}_{707-721}$-treated group was $74 \%$ compared with $93 \%$ in the control group. Both clinical signs of disease and histopathological studies revealed that $\mathrm{mCII}_{707-721}$-vaccinated mice had less joint inflammation than control peptide-vaccinated mice (Figure 12B). Prevention of inflammation in these mice was associated with sig- nificantly reduced numbers of $\mathrm{CD}^{+} \mathrm{T}$ cells in synovial infiltration (mean $\pm \mathrm{SD} ; 12 \pm 3$ vs. $37 \pm 7, n=10, P \leq 0.05$ ) and reduced production of IFN- $\gamma$, IL-4, and TNF- $\alpha$ (Figure 12, C and D), as determined by joint tissue immunohistochemistry staining. These results support the possibility of controlling arthritis by activation of $\mathrm{mCII}_{707-721}$-specific CD1d-restricted NKT cells.

Vaccination with $m \mathrm{CII}_{707-721}$ ameliorates EAE. The DTH and OVA sensitization experiments indicated that the suppressive quality of

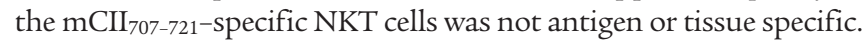
Therefore, we evaluated the effect of vaccination with $\mathrm{mCII}_{707-721}$ on EAE, a well-described Th1-mediated autoimmune disease affecting the CNS and a widely used experimental model for MS. EAE was 
A Gated on splenocytes

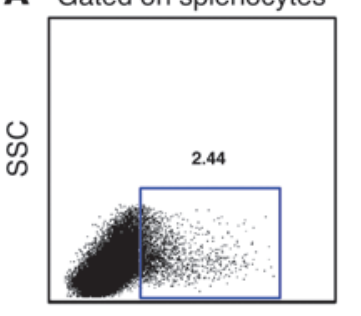

Gated on $\mathrm{CD}^{+} \mathrm{T}$ cells

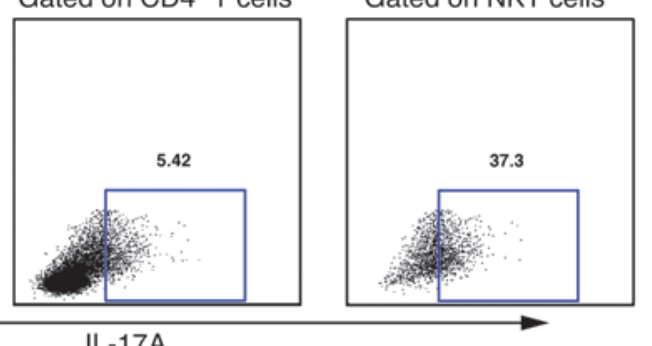

IL-17A

B

CD4 ${ }^{+} \mathrm{T}$ only

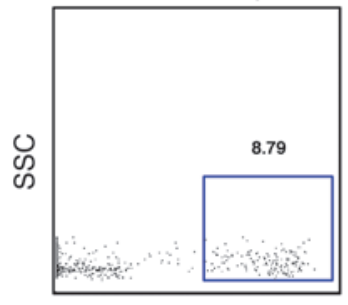

$\mathrm{CD}^{+} \mathrm{T}+\mathrm{NKT}$

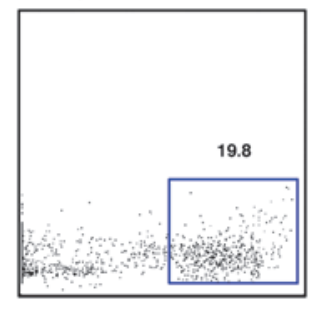

7AAD
$\mathrm{CD} 4+\mathrm{T}+\mathrm{NKT}+$ anti-IL-17A

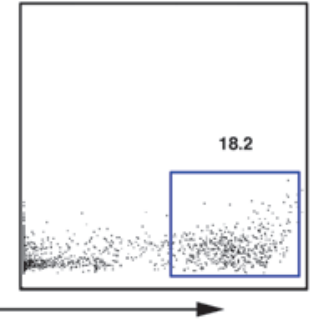

\section{Figure 9}

IL-17A from mCll ${ }_{707-721}-$ specific NKT cells does not affect suppression. (A) FACS with CD4, NK1.1, IL-17A antibodies and LIVE-DEAD marker from B10.Q WT mouse splenocytes 10 days after immunization with $\mathrm{mCll}_{707-721}$. One representative FACS is shown, with the percentage of IL-17A cells in CFSE-labeled splenocytes, CD4+ T cells, and CD4+ NK1.1+ NKT cells. (B) Single-cell spleen suspensions from B10.Q WT mice immunized with $\mathrm{mCll}_{707-721}$ stained for CD4 and NK1.1, purified by FACS. CD4+ T cells were stimulated with plate-bound anti-CD3 and cocultured for 48 hours with NKT cells with or without anti-IL-17A. Cell death was determined by $7 A A D$ staining. induced in B10.Q WT mice vaccinated with $\mathrm{mCII}_{707-721}$ by immunization with $\mathrm{MOG}_{79-96}$. EAE progression was significantly suppressed in $\mathrm{mCII}_{707-721}$-vaccinated mice, resulting in low mean clinical scores compared with the control group vaccinated with $\mathrm{mCI}_{707-721}$ (Figure 13A). Although no differences were seen between the 2 groups in disease incidence (both groups had $89 \%$ disease), affected mice in the $\mathrm{mCII}_{707-721-v a c c i n a t e d}$ group recovered entirely, while control group mice exhibited lingering symptoms up to 1 month after disease induction. In support, the CNS of $\mathrm{mCII}_{707-721}$-vaccinated mice showed significantly less demyelination than control mice (Figure 13, $\mathrm{B}$ and $\mathrm{C}$ ), which correlated well with the clinical findings and the general inflammation observed in the CNS (data not shown).

These data strongly support the capacity of $\mathrm{mCII}_{707-721}-\mathrm{spe}$ cific NKT cells to suppress a variety of inflammatory conditions, not limited to the Th1/Th2 paradigm nor restricted to collagentissue specificity.

\section{Discussion}

CD1d-restricted NKT cells exert profound and diverse regulatory effects in disease. They have deservedly earned the distinction of bridging the innate and adaptive immune systems, showing capacity for antiinflammation activity.

However, despite almost 2 decades of study, research on natural ligands of NKT cells has not resulted in identification of any selfpeptide ligands that could activate NKT cells. Many experimental systems and clinical models have focused on exogenous glycolipids (such as $\alpha$ GalCer) presented by CD1d and highly potent in activation of NKT cells. Although this approach has been important to the characterization of NKT cells' properties and functions, the biology of endogenous antigen-presentation by CD1d and activation of CD1d-dependent NKT cells remains largely unknown. The discovery of endogenous ligands, including self-peptide ligands that bind to CD1d, can shed light on the innate physiological functions of CD1d-dependent NKT cells. Our results support the idea that self-peptide reactivity could be considered part of the intrinsic immune function of NKT cells to maintain tolerance to self in cases of tissue inflammation.
We show here for what we believe is the first time a population of CD $4^{+} \mathrm{TCR} \alpha \beta^{+}$NKT cells with specificity for a self-tissue peptide that binds to CD1d. These CD1d-restricted $\mathrm{mCII}_{707-721^{-}}$specific NKT cells constitute an important component of the peripheral tolerance maintenance mechanism in that they protect against tissue-specific autoimmunity. Although $\mathrm{mCII}_{707-721}$-specific NKT cells are part of the peripheral pool of immune cells, they require activation via CD1d-self-antigen-TCR signaling to become competent immune regulators. Significantly, they suppress a range of inflammatory and autoimmune conditions.

Although CD1d has a large hydrophobic groove more suitable for the binding of glycolipids, studies have reinforced the notion that peptides can bind (9). How the $\mathrm{mCII}_{707-721}$ structurally fits into this groove is not clear. Other studies have shown that a CD1d-restricted peptide can elicit a cellular immune response in vivo (17), leading the researchers to opine that intracellular murine CD1d might normally be associated with peptides and therefore peptide presentation may be a true physiologic function of murine CD1d (8).

Here, we determined that $\mathrm{mCII}_{707-721}$ does bind to CD1d and has the capacity to be presented to NKT cells. In support of this observation, CD1d presentation of $\mathrm{mCII}_{707-721}$ to NKT cells upregulated phosphorylated ZAP-70, a tyrosine kinase that is crucial for productive stimulation of T cells through TCR signaling after activation of TCR/CD3 (18). We found that $\mathrm{mCII}_{707-721^{-}}$ specific NKT cells required costimulatory signals via B7.1/CD28 and CD40/CD40L pathways, supporting earlier studies on NKT cell activation requirements (19). The limited usage of $V \alpha$ and the V $\beta$ chain diversity in the TCR of NKT cells, combined with a nonpolymorphic CD1d, suggest that the CD1d-restricted NKT cells may recognize a single or conserved set of antigens. Although some skewing toward V $\alpha 14-J \alpha 18, V \beta 8.2$ TCR usage was observed in $\mathrm{mCII}_{707-721}$-reactive NKT cells, this response is far from being a clonal response. Instead, the $\mathrm{mCII}_{707-721}$ peptide activates a heterogeneous NKT cell population, as identified with a panel of V $\beta$ TCR that showed it to be polyclonal and diverse. Nonetheless, variations in CD1d-restricted antigen pre- 
A

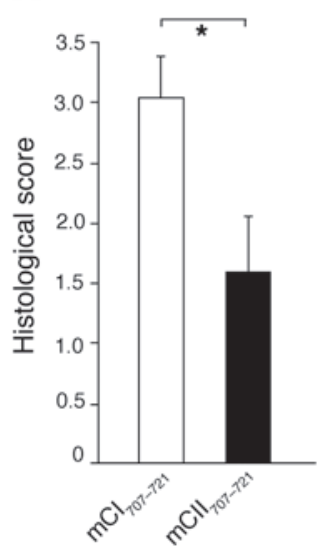

B

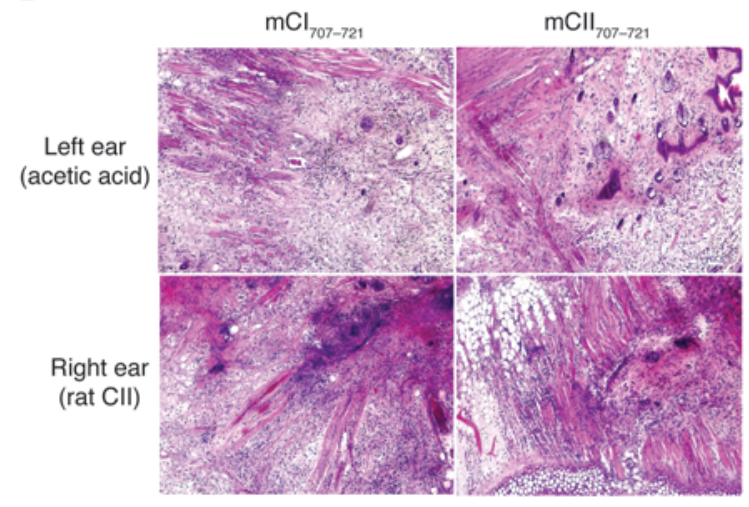

C

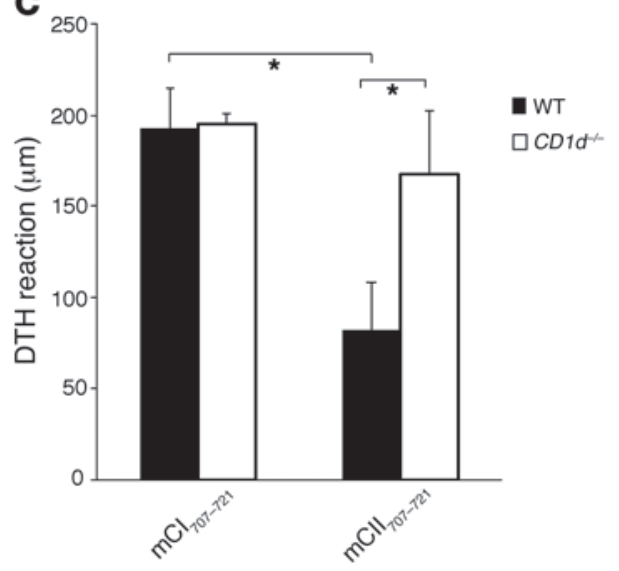

Figure 10

$\mathrm{mCll}_{707-721}-$ specific NKT cells suppress Th1 cell-mediated immune responses. (A and $\mathbf{B}$ ) In vivo activation of mCll ${ }_{707-721}-\mathrm{specific}$ NKT cells significantly reduced Th1-driven inflammation due to DTH induced by rat CIl, assessed by histopathological scoring of tissue inflammation. Data are mean $\pm \mathrm{SD}, n=6$ mice per group. ${ }^{*} P \leq 0.05$. Original magnification, $\times 100$. (C) DTH response in WT (B10.Q) is significantly lower than in $\mathrm{CD}_{1} \mathrm{~d}^{-/-}$mice. While $\mathrm{mCll}_{707-721}$ vaccination dampens $\mathrm{DTH}$ reaction, the $\mathrm{mCl}_{707-721}$-negative control peptide is inadequate to exert antiinflammatory effects. DTH response (ear swelling) was calculated by subtracting the thickness of the right ear from that of the left ear. Data are mean \pm SEM, $n=4-5$ mice per group. ${ }^{*} P \leq 0.05$.

sentation could arise from differences in expression, trafficking, processing, or loading of antigens (20).

We show that antigen-specific production of TGF- $\beta 1$, IFN- $\gamma$, and IL-4 by CD1d-restricted $\mathrm{mCII}_{707-721}$-specific NKT cells resembles conventional $\mathrm{T}$ cells in the adaptive immune response. IL-17 production is associated with CD4+NK1.1 $1^{+}$invariant NKT cells (21) and is suggested to be pathogenic in several autoimmune diseases $(22,23)$. However, the pathogenic role of IL-17-producing Th17 cells has also received challenges (24), and the regulatory role for regulatory $\mathrm{T}$ cells has been shown to be independent of their influence on Th17 (25). Still, a potential influence for IL-17-producing NKT cells on the regulation of autoimmune diseases could be plausible. In the present study, we found CD1d-restricted $\mathrm{mCII}_{707-721^{-}}$ specific NKT cells produced IL-17A, but it was not involved in their suppressive function. In support, CD1d-dependent NKT cells' regulation of arthritis is IL-17 independent (26).

Of note, the mCII ${ }_{707-721-}$-specific NKT cells suppressed anti-CD3activated $\mathrm{T}$ cells in a cell-cell contact-dependent manner. Cytokines including IL-4, IL-10, IL-13, and TGF- $\beta 1$ have been suggested as important mediators in NKT cell suppressive functions (10,27), so suppression mediated by a final release of cytokines upon cell interaction could be feasible. However, we detected no role for cytokine production by the $\mathrm{mCII}_{707-721}$-specific NKT cells in their in vitrosuppressive effects on $\mathrm{T}$ cells since neutralizing these cytokines did not prevent the suppressive effects. In our previous work, the regulatory role of CD1d-restricted NKT cells in EAE was associated with TGF- $\beta 1$ production in the CNS (28). While $\mathrm{mCII}_{707-721 \text {-specific }}$ NKT cells produce substantial levels of TGF- $\beta 1$ upon restimulation, the suppressive function of this cell population on $\mathrm{T}$ cell proliferation is independent of TGF- $\beta 1$-TGF- $\beta$ receptor interaction. This does not rule out the possibility that NKT cells could exert their regulatory functions in inflamed tissues via TGF- $\beta 1$ secretion, since NKT cells may target cell types other than $\mathrm{T}$ cells. Interestingly, $\mathrm{mCII}_{707-721}$-specific NKT cells induced FasL-mediated apoptosis in activated $\mathrm{T}$ cells, similar to the killing of tumor cells by $\alpha$ GalCer-activated NKT cells (29). Consistent with other studies that show regulation of $\mathrm{T}$ cells by NKT cells through the use of Fas-FasL $(30,31)$, our data suggest that this could be one pathway by which physiologically relevant self-antigen-reactive NKT cells limit autoreactive $\mathrm{T}$ cells and prevent chronicity of tissue inflammation. We show that cytotoxicity of NKT cells against activated $\mathrm{T}$ cells was completely Fas-dependent in vitro and partially so in vivo. It is thus possible that when the Fas/FasL pathway is defective, other pathways could operate to mediate $\mathrm{mCII}_{707-721}$-specific NKT cell-mediated suppression. This possibility is supported by studies in a myelomonocytic leukemia cell line, in which human NKT cells were shown to utilize multiple cytotoxic mechanisms, including perforin/granzyme-B, TNF- $\alpha$, FAS-L, and TRAIL in vitro (32).

With clear indications that the self $\mathrm{mCII}_{707-721}$-specific $\mathrm{NKT}$ cell population could suppress activated $\mathrm{T}$ cell responses and dampen inflammation, we investigated whether it could also regulate tissuespecific inflammation and autoimmunity in mice. Using a Th1driven DTH assay and a Th2-driven antigen-induced airway inflammation, we found, unexpectedly, that $\mathrm{mCII}_{707-721}$-specific NKT cell activation reduced both the Th1-mediated DTH reaction and the Th2 cytokine response, and lowered IgE production. Thus, CD1d-

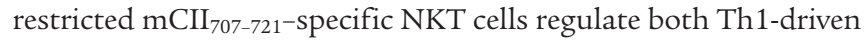
states and diminish humoral Th2 responses. Vaccination of mice with $\mathrm{mCII}_{707-721}$ prior to CIA induction significantly ameliorated arthritis, as evinced by lower clinical and histopathological scores. Significantly lower joint inflammation was accompanied by reduction of all tested cytokines but no alteration of the Th1/Th2 profile of cells infiltrating the joints. In accordance, recently we reported that general activation of CD1d-dependent NKT cells in WT mice prevents arthritis in different models of joint inflammation without induction of a cytokine shift, while CD1d-deficient mice lacking this population are defective in suppressing joint inflammation (26).

Given that NKT cells can either suppress or activate immunity, their therapeutic use necessitates a thorough understanding of their intrinsic biology. Limitations in this regard have been revealed by $\alpha$ GalCer or its synthetic analogs, which despite some success in early clinical trials have on the whole been less promising (33-35). 
A
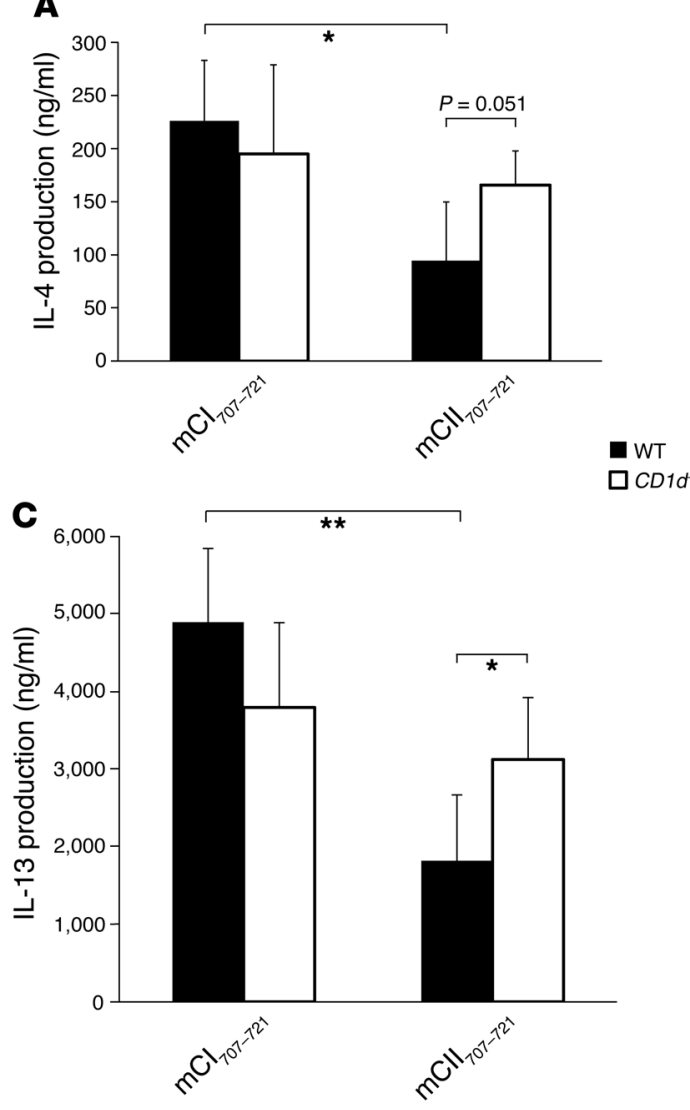

B

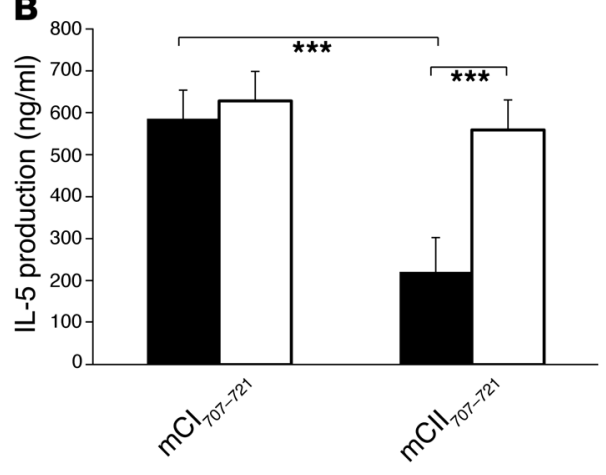

CD1atr

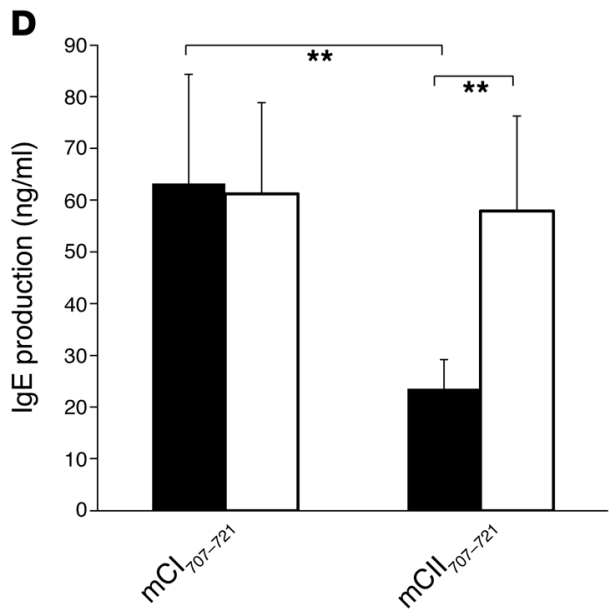

Figure 11

Activation of $\mathrm{mCll}_{707-721}-\mathrm{spe}$ cific CD1d-restricted NKT cells in vivo significantly reduces Th2-mediated responses to OVA. (A-D) Expression of IL-4, IL-5, IL-13, and IgE were all significantly reduced in BALF of $\mathrm{mCll}_{707-721}-\mathrm{vaccinated}$ B10.Q mice compared with all control-vaccinated groups of mice. $C D 1 d^{-/-}$mice lack such $\mathrm{mCll}_{707-721}$-mediated antiinflammatory effects. Data are mean $\pm \mathrm{SD}, n=4-5$ mice per group. ${ }^{\star} P \leq 0.05 ;{ }^{*} P \leq 0.01$; ${ }^{* * *} P \leq 0.001$
This could perhaps be attributed to the fact that these substances are not found in self tissues and hence fail to replicate the natural course of NKT cell activation in disease. $\mathrm{mCII}_{707-721^{-}}$-specific NKT cells may be able to overcome these obstacles and achieve fuller potential as treatments for autoimmune diseases and cancer.

A natural question emerging from the currently reported results regards the tissue specificity of the autoimmune suppressive function of activated $\mathrm{mCII}_{707-721}$-specific NKT cells. Therefore, we investigated its effect on inflammation of the CNS via an EAE model. Mice vaccinated with $\mathrm{mCII}_{707-721}$ prior to induction of EAE showed significantly reduced clinical symptoms and demyelination compared with the control group. We surmise that even if the population of NKT cells is self-collagen specific, their suppressive function is not necessarily restricted to arthritis and cartilage tissue but can operate in other tissue-specific autoimmune and inflammatory diseases.

The question of how the $\mathrm{mCII}_{707-721}$-specific NKT cells regulate autoimmunity in multiple models, specifically with regard to their effects on autoreactive T cells, is of interest. This ability is consistent with properties of conventional regulatory $\mathrm{T}$ cells (36) as well as antigen-specific regulatory $\mathrm{T}$ cells generated in inflamed tissues such as those of the CNS (37). Antigen-nonspecific responses of NKT cells, or bystander suppression, could involve different mechanisms. One of the widely discussed ideas is the ability of NKT cells, even in a non-self-antigen-specific manner (e.g., $\alpha$ GalCer or its analogs), to regulate multiple autoimmune diseases via their capacity to produce an early burst of cytokines and deviation of the Th1/Th2 axis (reviewed in ref. 38). However, the suppressive function of $\mathrm{mCII}_{707-721}$-specific NKT cells differs since we detected a cell-cell-mediated mechanism. This is consistent with an earlier report (39) in which it was shown that NKT cells inhibited the differentiation of naive autoreactive $T$ cells into effector cells. Here we have shown that the suppressive function of

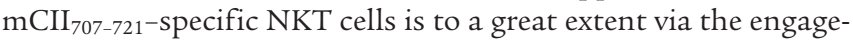
ment of the Fas/FasL pathway. This supports a model whereby activation of autoreactive NKT cells could inhibit further effector $\mathrm{T}$ cell activation via a direct cytolytic effect.

Alternatively, the suppressive function of the NKT cells may also be mediated by differential engagement of or effects on tissue-specific APCs such as macrophages (40), mature/immature DCs (41), and/or B-1 B cells (42). The ability of NKT cells to modulate the function of APCs, as discussed in a recent review (6), may therefore play an important role in shaping the outcome of the immune response. Hence, differential engagement of APCs in different tissues, as the consequence of $\mathrm{mCII}_{707-721}$-specific NKT cell activation, may also serve a broad immune regulatory function.

The results of the present study support the contention that selfantigenic peptide-reactive NKT cells could be an important part of the peripheral tolerance maintenance mechanisms. Their physiological role may be to maintain tissue homeostasis through induction of cell-cell-mediated cytotoxic action on activated lymphocytes and to dampen inflammation regardless of the Th profile of its source. This is in contrast to the rapid release of cytokines traditionally assigned to the mode of action of NKT cells. Given that the joint is prone to wear and tear, the presence of this peptide-specific NKT cell population in the periphery could be part of the native physiology that might partly explain the relative resistance to mouse type II collagen-induced arthritis that is observed. As a general phenomenon 
A

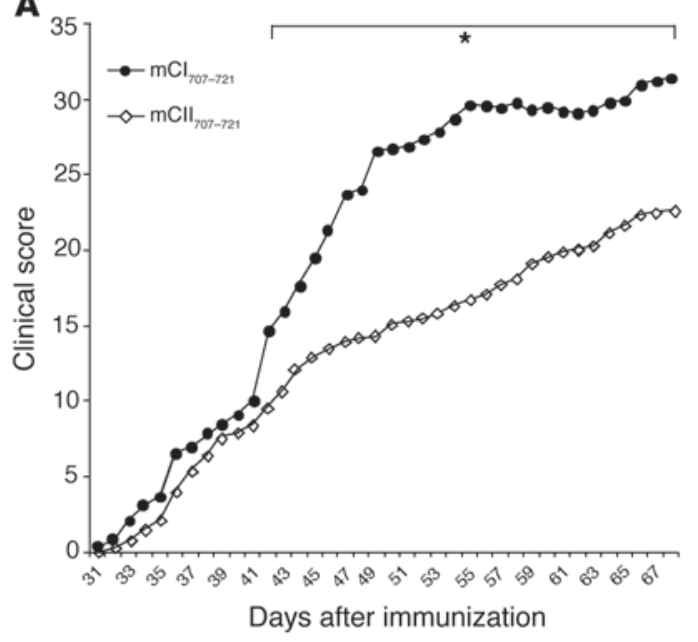

B
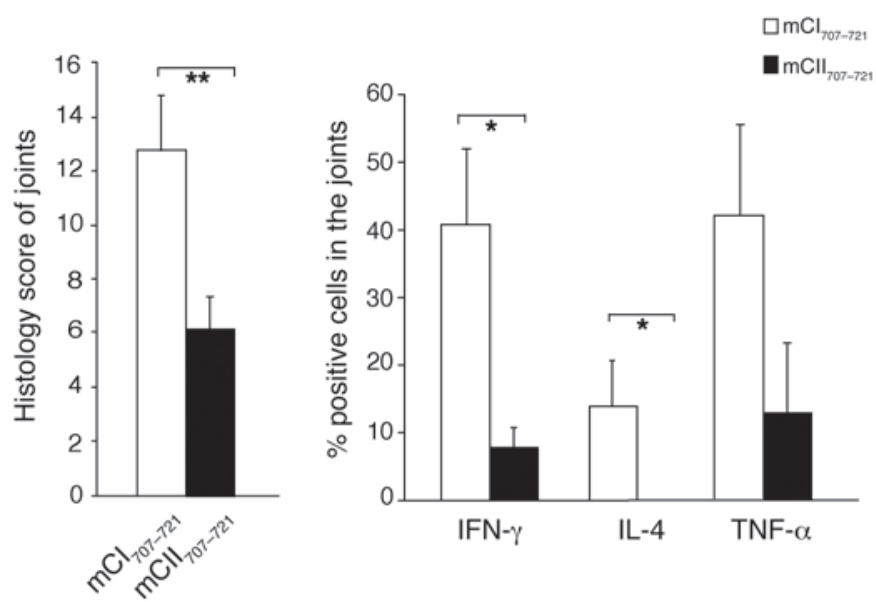

C

IFN- $\gamma$

IL-4 TNF- $\alpha$

D

CD4

IFN- $\gamma$

IL-4
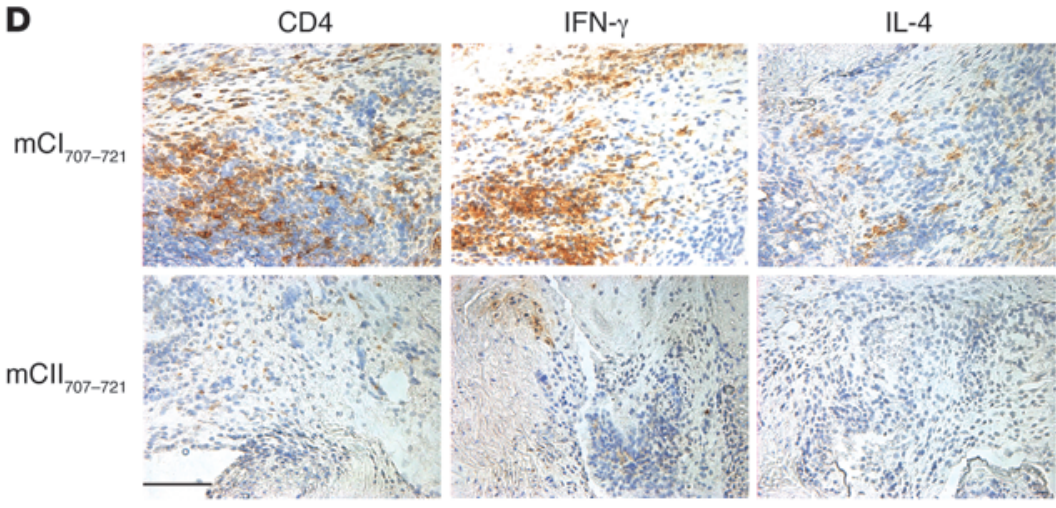

\section{Figure 12}

Activation of $\mathrm{mCll}_{707-721}-$ specific NKT cells suppresses arthritis. (A) Prevaccination of B10.Q mice with mCll ${ }_{707-721}$ significantly reduced severity by $\mathrm{ClA}$ clinical scoring compared with control peptide $\left(\mathrm{mCl}_{707-721}\right)$ vaccination (14 mice per $\mathrm{mCl}_{707-721}$ group, 19 mice per mCll ${ }_{707-721}$ group; ${ }^{*} P \leq 0.05$ ). (B) Histological arthritic scores by H\&E staining of joints. Data are mean $\pm \mathrm{SD}, n=5 .{ }^{* \star} P \leq 0.01$. (C) Histological scores of percentage of IFN- $\gamma-$, IL-4-, and TNF- $\alpha$-positive cells were significantly reduced in the $\mathrm{mCll}_{707-721}$-vaccinated group. Data are mean $\pm \mathrm{SD}, n=5$. ${ }^{*} P \leq 0.05$. (D) Suppression of arthritis was associated with reduced CD4+ $\mathrm{T}$ cell-infiltrating cells, IFN- $\gamma-$, and IL-4-producing cells by immunohistochemistry staining of joints. Red-brown color shows positively stained cells. Scale bar: $100 \mu \mathrm{m}$.

across a range of disease states, such cells could act rapidly toward any danger signal evoked by pathogens or inflammatory conditions. The effect would be to prevent chronicity of the inflammation and hence sustain immune balance and tissue homeostasis. Given the high degree of conservation of NKT cells among species, therapeutic immunization with an NKT-activating peptide may hold promise for clinical benefit in human inflammatory diseases.

\section{Methods}

Mice. Animals were kept and bred at the animal facilities of the University of Lund or the University of Copenhagen. All animal experiments were reviewed and approved by both of these universities' institutional review boards, located in Lund and Copenhagen, respectively. All studies with mCII $_{707-721}$ were performed on WT male C57BL/10.H-2q (B10.Q) mice (originated from Jan Klein, University of Tubingen, Tubingen, Germany). KO mice were backcrossed to this background to produce well-controlled genetic strains to avoid strain-specific effects that might influence the results.

$\mathrm{Tcrab}^{-/-}$or $\mathrm{Tcrgd}^{-/-}$mice were the results of targeted germ-line mutations on 129 and backcrossed to C57BL/6J (The Jackson Laboratory). These were backcrossed to the B10.Q background for 6 generations. Subsequent intercrossing of mice heterozygous or homozygous for mutated TCR yielded homozygous ( $\alpha \beta$ or $\gamma \delta$ T cell deficient) and heterozygous (normal T cell phenotype) littermates. $\mathrm{T}$ cell phenotypes were determined by flow cytometry analysis of blood cells using mAbs against either TCR $\alpha \beta$ (H57-597-FITC; Pharmingen) or TCR $\gamma \delta$ (GL3-PE; Pharmingen).

CD4- and CD8-deficient founders backcrossed to C57BL/6J mice (43) were backcrossed to B10.Q for 10 generations, and positive offspring were intercrossed twice to yield littermates homozygous for the WT gene, homozygous for the disrupted gene, or heterozygous, as determined by flow cytometry with anti-CD4 (Gk1.5-PE; BD) and anti-CD8 (53-6.7-biotin: BD Biosciences - Pharmingen) mAbs.

MHC II-deficient and TAP-deficient mice (originally received from Diana Mathis, Institute of Genetics and Molecular and Cellular Biology, University of Strasbourg, Strasbourg, France) were backcrossed to C57BL/6J for 20 generations and then backcrossed to B10.Q for 3 generations. The offspring deficient in targeted genes were intercrossed once to yield homozygous KO or WT, and heterozygous littermates. lpr mice of H-2q haplotype were received from Saleh Ibrahim (Department of Immunology, Rostock University). 

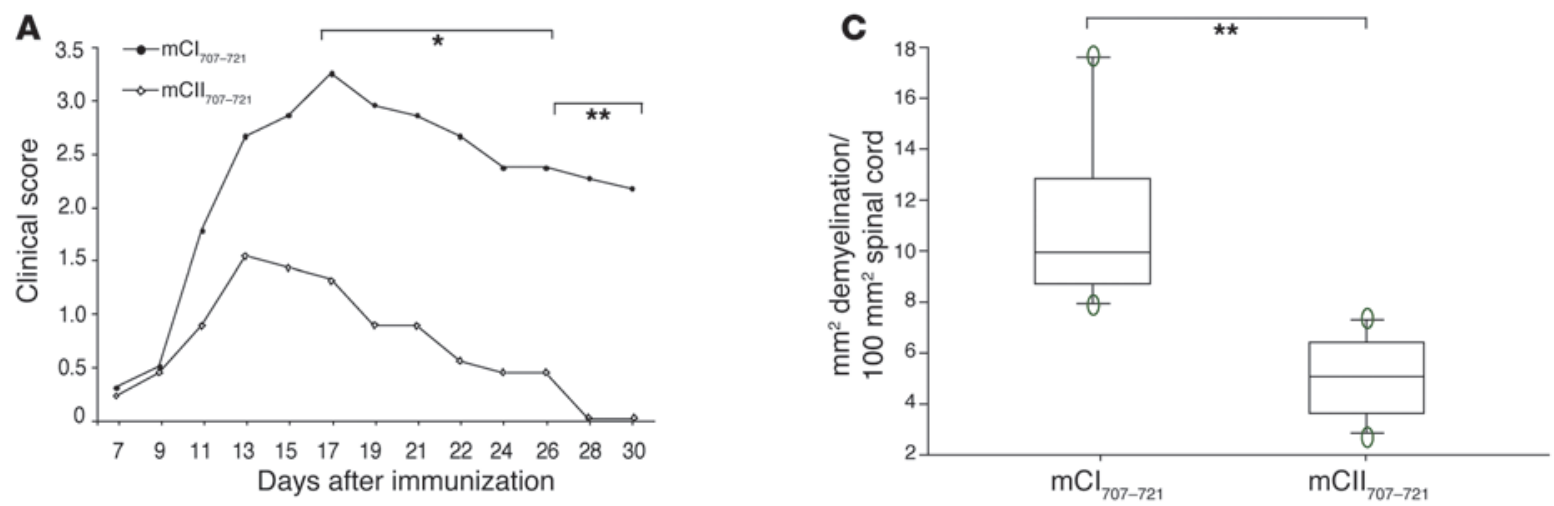

B
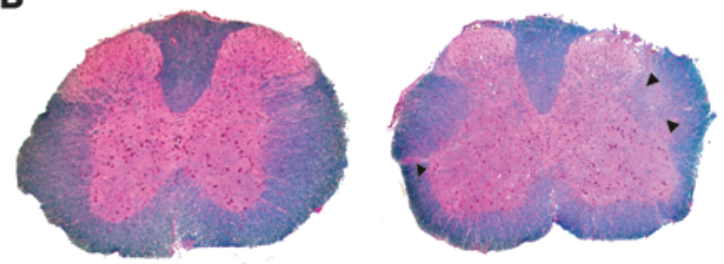

\section{Figure 13}

Activation of $\mathrm{mCll}_{707-721}$-specific NKT cells suppresses EAE neurological deficits. (A) Prevaccination of B10.Q mice with mCll ${ }_{707-721}$ significantly reduced EAE clinical scoring compared with control peptide ( $\left.\mathrm{mCl}_{707-721}\right)$ vaccination. $n=9-10$ mice per group. ${ }^{\star} P \leq 0.05 ;{ }^{\star *} P \leq 0.01$. (B and $\mathbf{C}$ ) Demyelination in CNS was significantly reduced in $\mathrm{mCll}_{707-721}$-vaccinated mice. (B) Representative sections of spinal cord from a $\mathrm{mCl} \mathrm{I}_{707-721}-$ vaccinated mouse (left) and control (right). Arrows show demyelinated areas in white matter. Original magnification, $\times 25$. (C) Demyelination was calculated as $\mathrm{mm}^{2}$ of demyelination per $100 \mathrm{~mm}^{2}$ spinal cord, $n=3$ mice per group. Data are median $\pm \mathrm{SD}$. ${ }^{* *} P \leq 0.01$.

CD1 $d^{-/-}$mice (44) on a C57BL/6J background (over 20-generation backcross) were backcrossed to B10.Q for more than 5 generations. Animals were sex and age matched (8-20 weeks) for all experiments.

Media and reagents. All cells were grown in cDMEM, DMEM with Glutamax-1 (GIBCO BRL, Life Technologies) supplemented with $10 \mathrm{mM}$ HEPES buffer, $10 \%$ heat-inactivated FCS, $0.16 \mu \mathrm{M} / \mathrm{ml}$ penicillin, $0.03 \mu \mathrm{M} / \mathrm{ml}$ streptomycin, and $50 \mu \mathrm{M} 2$-mercaptoethanol. Growth was in a humidified incubator at $37^{\circ} \mathrm{C}$ with $7.5 \% \mathrm{CO}_{2}$. All reagents were from Sigma-Aldrich, unless otherwise noted.

All peptides were from Schäfer. Mouse collagen type II peptide mCII $707-721$ (PPGANGNPGPAGPPG) and negative control mouse collagen type I peptide $\mathrm{mCI}_{707-721}$ (PPGPSGNAGPPGPPG) differ at positions 710 (proline to alanine), 711 (serine to asparagine), 714 (alanine to proline), and 717 (proline to alanine). Biotinylated peptides were used in binding assays.

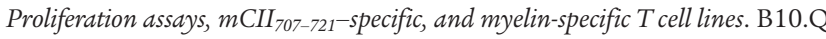
male mice, aged 8-14 weeks, were immunized in the hind paws and tail base with $200 \mu \mathrm{l}$ of a 1:1 emulsion of $100 \mu \mathrm{g}$ of either $\mathrm{mCII}_{707-721}$ or $\mathrm{mCI}_{707-721}$ in PBS and CFA containing Mycobacterium tuberculosis H37Ra (Difco). For some experiments, B10.Q and a panel of KO mice on a B10.Q background were used. Draining LNs or spleens were collected on days 10-13 after immunization, and a single-cell suspension was prepared in PBS by passing through a sieve. Cells were washed and resuspended in cDMEM.

To measure $\mathrm{T}$ cell proliferation in response to $\mathrm{mCII}_{707-721}$, cells were cultured in quadruplicate in round-bottom 96 -well plates (Nunc) at $5 \times 10^{5}$ cells/ well and stimulated with $100 \mu \mathrm{g} / \mathrm{ml} \mathrm{mCII} \mathrm{m}_{707-721}$ or $\mathrm{mCI}_{707-721}$ and/or media only or PPD for 4 days in the presence of $1 \mu \mathrm{Ci}{ }^{3} \mathrm{H}$-thymidine per well in the final 12 hours of culture. ${ }^{3} \mathrm{H}$-thymidine incorporation was measured in a beta scintillation counter (Matrix 96 Direct Beta Counter; Packard). $\mathrm{mCII}_{707-721}$-specific and myelin-specific $\mathrm{T}$ cell lines were established as previously published (37).
Blocking antibodies were anti-CD40L $(20 \mu \mathrm{g} / \mathrm{ml})$; anti-CTLA-4 $(5 \mu \mathrm{g} / \mathrm{ml})$; anti-B7.1 Fab-fragment $(20 \mu \mathrm{g} / \mathrm{ml})$; anti-B7.2 Fab-fragment $(20 \mu \mathrm{g} / \mathrm{ml})$; CTLA-4-lg fusion protein $(10 \mu \mathrm{g} / \mathrm{ml})$; and isotype controls $(10 \mu \mathrm{g} / \mathrm{ml})$.

CD1d-binding assay. Maxisorp plates (Nunc) were coated with recombinant soluble dimeric mouse CD1d-lg dimer (BD Biosciences - Pharmingen) at $4 \mu \mathrm{g} /$ well. Biotin-labeled $\mathrm{mCII}_{707-721}(0.6 \mu \mathrm{g} /$ well $)$ was added and incubated at $37^{\circ} \mathrm{C}$ for 2 hours. After washing, plates were incubated with europium-avidin followed by enhancement buffer according to the manufacturer's instructions and fluorescence intensity measured on a fluorometer (Wallac Oy EG \& G). Biotin-labeled anti-CD1d was a positive control, and biotin-labeled $\mathrm{mCI}_{707-721}$ was the negative control. Nonlabeled $\mathrm{mCII}_{707-721}$ in excess or varying amounts of $\alpha$ GalCer was used to assess competitive binding.

Ratio of binding for $\mathrm{mCII}_{707-721}$ to $\mathrm{CD} 1 \mathrm{~d}$ was calculated by dividing the fluorometer OD value by the OD value for the positive control, for different $\mathrm{mCII}_{707-721}$ concentrations.

FACS. Standard FACS procedures and analysis were followed (45). Antibodies were from BD Biosciences - Pharmingen unless stated otherwise and used at 1-5 $\mu \mathrm{g} / \mathrm{ml}$, and were PE-Cy5-anti-CD4 (GK1.5), FITC-anti-TCR- $\beta$ (H57-597), mouse V $\beta$ TCR screening panel (cat. no. 557004), PE-anti-IL-4 (11B11), PE-anti-IFN- $\gamma$ (XMG1.2), biotin-antiTGF- $\beta 1$ (A75-3.1), streptavidin-PE (cat. no. 554061), APC-anti-TNF- $\alpha$ (MP6-XT22), PE-anti-IL-17A (TC11-18H10), PE-anti-CD49b (DX5), FITC- and PE-anti-NK1.1 (Pk136).

Real-time PCR. To detect TCR V $\alpha 14-J \alpha 18$ expression, total RNA was extracted from the NKT cell line using a QIAGEN kit, reverse transcribed, and amplified and quantified by SYBR Green detection. Primers were Va14-Ja18 primer, forward: 5'-TGGGAGATACTCAGCAACTCTGG-3'; reverse: 5'-CAGGTATGACAATCAGCTGAGTCC-3'; and constant region housekeeping forward: 5'-CCTCTGCCTGTTCACCGACTT-3'; reverse: $5^{\prime}$-TGGCGTTGGTCTCTTTGAAG-3'. PCR was 10 minutes at $95^{\circ} \mathrm{C}$, 
40 cycles of $95^{\circ} \mathrm{C}$ for 10 seconds, decreasing by $20^{\circ} \mathrm{C} / \mathrm{s}$ to $60^{\circ} \mathrm{C}$, and $60^{\circ} \mathrm{C}$ for 60 seconds. The melting curve was $20^{\circ} \mathrm{C} / \mathrm{s}$ to $95^{\circ} \mathrm{C}$, cooling at $20^{\circ} \mathrm{C} / \mathrm{s}$ to $60^{\circ} \mathrm{C}$, and heating at $0.2^{\circ} \mathrm{C} / \mathrm{s}$ to $95^{\circ} \mathrm{C}$ with fluorescence collection at $0.2^{\circ} \mathrm{C}$ intervals.

ELISA. ELISAs were performed according to the manufacturers' instructions. ELISA kits were used for IL-13 and IgE (BD Biosciences) and IL-4, IL-5, IFN- $\gamma$, TNF- $\alpha$, and TGF- $\beta 1$ (R\&D Systems).

Purification of NKT cells. Single-cell suspensions were washed and resuspended in 2\% FCS in PBS with APC-CD4 and PE-NK1.1 for 20 minutes at $4{ }^{\circ} \mathrm{C}$. Cells were washed with $2 \%$ FCS in PBS and analyzed or purified using FACSAria. $\mathrm{CD} 4^{+} \mathrm{T}$ cells and $\mathrm{CD} 4^{+} \mathrm{NK} 1.1^{+} \mathrm{NKT}$ cells were purified with FACSAria.

In vitro suppressive assays. Splenocytes from B10.Q mice or a conventional B10.Q MOG $_{79-96}$-specific $\mathrm{T}$ cell line were activated by culturing on platebound anti-CD3 at $5 \mu \mathrm{g} / \mathrm{ml}$ and used as responder cells by coculturing at a 1:1 ratio with $\mathrm{mCII}_{707-721}$-specific NKT cells. Proliferation was measured by ${ }^{3} \mathrm{H}$-thymidine incorporation. When splenocytes were responder cells, the B10.Q MOG $_{79-96}$-specific cells were used as controls. Blocking antibodies were added to the NKT cells for 30 minutes before coculture.

ATranswell insert of $0.4 \mu \mathrm{m}$ (Falcon) was used for separation of $\mathrm{mCII}_{707-721^{-}}$ specific NKT and responder cells. Soluble molecules, but not cells, could pass through the insert.

For annexin $V$ staining, cells were incubated in binding buffer with $5 \mu \mathrm{l}$ of annexin $\mathrm{V}-\mathrm{PE}$ at room temperature for 5 minutes in the dark and washed. Positive cells were monitored by FACS. Some experiments used 7AAD instead of annexin $\mathrm{V}$.

Vaccination with $m \mathrm{CII}_{707-721}$, OVA challenge, induction of DTH, CIA, and EAE. Mice were immunized in the flank with $100 \mu \mathrm{g} \mathrm{mCII}_{707-721}$ emulsified 1:1 in CFA 10 days prior to disease induction. Control mice were similarly immunized with $\mathrm{mCI}_{707-721}$ and/or CFA (vehicle).

DTH response. B10.Q mice and $\mathrm{CD} 1 \mathrm{~d} \mathrm{KO}$ mice received an intradermal injection at the tail base with $100 \mu \mathrm{g}$ of CII emulsified in CFA (Difco). At 13 days after immunization, mice received an injection of $20 \mu \mathrm{g} \mathrm{CII}$ in $0.05 \mathrm{M}$ acetic acid in the outer right ear and just acetic acid in the outer left ear as a negative control. Additional control groups vaccinated with $\mathrm{mCI}_{707-721}$ and/or CFA (vehicle) were included when specified. After 48 hours, the DTH response was measured using a Krœplin caliper and calculated as the difference in swelling (thickness) of the right and left outer ears. Histopathological evaluation of inflammation in the outer ears was also performed.

OVA sensitization and BALF. B10.Q and CD1d KO mice received an intraperitoneal injection on days 0 and 4 with $50 \mu \mathrm{g}$ OVA with $5 \mathrm{mg}$ alum. At day 13 , mice were challenged with $50 \mu \mathrm{g}$ of OVA intranasally. Mice were sacrificed 24 hours later and BALF collected for ELISA.

Induction and evaluation of CIA. Male B10.Q mice, 8-12 weeks of age, were immunized intradermally at the tail base with $100 \mu \mathrm{g}$ rat collagen emulsi- fied in CFA (Difco) and boosted at day 35 with $50 \mu \mathrm{g}$ rat CII emulsified in incomplete Freund adjuvant (Difco). Clinical scoring was performed as described (46). For histopathological and immunohistochemical analyses, ankle joints were removed on day 31 after collagen immunization (47). For immunohistochemistry, cryosections were stained with biotinylated antibodies to IFN- $\gamma$ (Ani8), IL-4 (BVD6-24G2), TNF- $\alpha$ (MP6-XT3), and CD4 (L3T4). ExtrAvidin-peroxidase and diaminobenzidine $(50 \mathrm{mg} / \mathrm{ml}$; Saveen Biotech) were used for detection, with background hematoxylin staining. For cytokines, $0.1 \%$ saponin was used at all steps after fixation. Stained infiltrating cells were counted in the synovium by randomly selecting 6 areas per section and calculating the mean of positive cells per animal.

Induction and evaluation of EAE. B10.Q mice were immunized for induction of EAE, as described (37).

For demyelination, the lumbar part of spinal cords from 3-4 mice per group was collected at day 40 after MOG immunization and fixed in $4 \%$ formaldehyde and then as described (48). Results are the mean from 4 sections.

Statistics. Statistical evaluation was performed using StatView software. The Mann-Whitney test was used to analyze differences in clinical scores; otherwise a Student's unpaired 2-tailed $t$ test was used.

\section{Acknowledgments}

This work has been supported by grants from the Danish Multiple Sclerosis Society; a generous grant from the Lundbeck Foundation, Denmark; the Danish Research Council - Medicine; the Swedish Rheumatism Association; Börje Dahlins Fond; the Swedish Research Council - Medicine; the Swedish Research Council Natural Sciences; the Swedish Foundation for Strategic Research (SSF); the Crafoordska Foundation; the G-J Kocks Foundation; the Åke Wiberg Foundation; the Alfred Österlunds Foundation; the Tore Nilson Foundation; the Konung Gustaf V:s 80 Årsfond; the M. Bergvalls Foundation; the Swedish Association of Neurologically Disabled; Trygg-Hansa; the Bibi and Nils Jensen Foundation; and the EU-supported project MASTERSWITCH (HEALTH-F22008-223404). This publication reflects only the authors' views. The European Community is not liable for any use that may be made of the information herein.

Received for publication June 9, 2010, and accepted in revised form October 27, 2010.

Address correspondence to: Shohreh Issazadeh-Navikas, Neuroinflammation Unit, Biotech Research and Innovation Centre, University of Copenhagen, Denmark. Ole Maaløes Vej 5, DK-2200, Danish Biocenter, Copenhagen N, Denmark. Phone: 45.3532.5649; Fax: 45.3532.5669; E-mail: shohreh.issazadeh@bric.ku.dk.
1. Issazadeh S, Kjellen P, Olsson T, Mustafa M, Holmdahl R. Major histocompatibility complexcontrolled protective influences on experimental autoimmune encephalomyelitis are peptide specific. Eur J Immunol. 1997;27(6):1584-1587.

2. Brunsberg $U$, et al. Expression of a transgenic class II Ab gene confers susceptibility to collagen-induced arthritis. Eur J Immunol. 1994;24(7):1698-1702.

3. Holmdahl R, Jansson L, Larsson E, Rubin K, Klareskog L. Homologous type II collagen induces chronic and progressive arthritis in mice. Arthritis Rheum. 1986;29(1):106-113.

4. Bayrak S, et al. T cell response of I-Aq mice to self type II collagen: meshing of the binding motif of the I-Aq molecule with repetitive sequences results in autoreactivity to multiple epitopes. Int Immunol. 1997;9(11):1687-1699.
5. Bendelac A, Savage PB, Teyton L. The biology of NKT cells. Annu Rev Immunol. 2007;25:297-336.

6. Gapin L. iNKT cell autoreactivity: what is 'self' and how is it recognized? Nat Rev Immunol. 2010; 10(4):272-277.

7. Castano AR, et al. Peptide binding and presentation by mouse CD1. Science. 1995;269(5221):223-226.

8. Tangri S, Brossay L, Burdin N, Lee DJ, Corr M, Kronenberg $M$. Presentation of peptide antigens by mouse CD1 requires endosomal localization and protein antigen processing. Proc Natl Acad Sci US A. 1998;95(24):14314-14319.

9. Zeng Z, Castaño AR, Segelke BW, Stura EA, Peterson PA, Wilson IA. Crystal structure of mouse CD1: An MHC-like fold with a large hydrophobic binding groove. Science. 1997;277(5324):339-345.

10. Godfrey DI, Kronenberg M. Going both ways: immune regulation via CD1d-dependent NKT cells. J Clin Invest. 2004;114(10):1379-1388.

11. van der Vliet HJ, et al. The immunoregulatory role of CD1d-restricted natural killer T cells in disease. Clin Immunol. 2004;112(1):8-23.

12. Cardell S. The natural killer T lymphocyte: a player in the complex regulation of autoimmune diabetes in non-obese diabetic mice. Clin Exp Immunol. 2005; 143(2):194-202.

13. Van Kaer L. alpha-Galactosylceramide therapy for autoimmune diseases: prospects and obstacles. Nat Rev Immunol. 2005;5(1):31-42.

14. Mallevaey T, et al. T cell receptor CDR2 beta and CDR3 beta loops collaborate functionally to shape the iNKT cell repertoire. Immunity. 2009;31(1):60-71.

15. Nagata S. Fas-induced apoptosis, and diseases 
caused by its abnormality. Genes Cells. 1996; $1(10): 873-879$

16. Lee KA, et al. A distinct subset of natural killer T cells produces IL-17, contributing to airway infiltration of neutrophils but not to airway hyperreactivity. Cell Immunol. 2008;251(1):50-55.

17. Lee DJ, Abeyratne A, Carson DA, Corr M. Induction of an antigen-specific, CD1-restricted cytotoxic T lymphocyte response In vivo. J Exp Med. 1998; 187(3):433-438.

18. Chan AC, et al. Activation of ZAP-70 kinase activity by phosphorylation of tyrosine 493 is required for lymphocyte antigen receptor function. EMBOJ. 1995;14(11):2499-2508.

19. Uldrich AP, et al. NKT cell stimulation with glycolipid antigen in vivo: costimulation-dependent expansion, Bim-dependent contraction, and hyporesponsiveness to further antigenic challenge. J Immunol. 2005;175(5):3092-3101.

20. Brossay L, Tangri S, Bix M, Cardell S, Locksley R, Kronenberg M. Mouse CD1-autoreactive T cells have diverse patterns of reactivity to CD1+ targets. J Immunol. 1998;160(8):3681-3688.

21. Coquet JM, et al. Diverse cytokine production by NKT cell subsets and identification of an IL-17producing CD4-NK1.1- NKT cell population. Proc Natl Acad Sci U S A. 2008;105(32):11287-11292.

22. Koenders MI, van den Berg WB. Translational mini-review series on Th17 cells: are T helper 17 cells really pathogenic in autoimmunity? Clin Exp Immunol. 2010;159(2):131-136.

23. Fouser LA, Wright JF, Dunussi-Joannopoulos K, Collins M. Th17 cytokines and their emerging roles in inflammation and autoimmunity. Immunol Rev. 2008;226:87-102.

24. Haak S, et al. IL-17A and IL-17F do not contribute vitally to autoimmune neuro-inflammation in mice. J Clin Invest. 2009;119(1):61-69.

25. Liu Y, Teige I, Ericsson I, Navikas V, IssazadehNavikas S. Suppression of EAE by oral tolerance is independent of endogenous IFN-beta whereas treatment with recombinant IFN-beta ameliorates EAE. Immunol Cell Biol. 2010;88(4):468-476.

26. Teige A, Bockermann R, Hasan M, Olofsson KE, Liu Y, Issazadeh-Navikas S. CD1d-dependent NKT cells play a protective role in acute and chronic arthritis models by ameliorating antigen-specific Th1 responses. J Immunol. 2010;185(1):345-356.

27. Ito $H$, Seishima M. Regulation of the induction and function of cytotoxic $\mathrm{T}$ lymphocytes by natural killer T cell. J Biomed Biotechnol. 2010;2010:641757.

28. Teige A, et al. CD1-dependent regulation of chronic central nervous system inflammation in experimental autoimmune encephalomyelitis. J Immunol. 2004;172(1):186-194.

29. Kawano T, et al. Natural killer-like nonspecific tumor cell lysis mediated by specific ligand-activated Valpha14 NKT cells. Proc Natl Acad Sci U S A. 1998;95(10):5690-5693

30. Arase N, Arase H, Good RA, Onoe K. Contribution of host radioresistant $\mathrm{T}$ cells to the clonal elimination of minor lymphocyte stimulatory-1a reactive $T$ cells in mouse bone marrow chimeras. Cell Immunol. 1994;156(1):13-23.

31. Moroda T, et al. Autologous killing by a population of intermediate T-cell receptor cells and its NK1.1+ and NK1.1- subsets, using Fas ligand/Fas molecules. Immunology. 1997;91(2):219-226.

32. Metelitsa LS, Weinberg KI, Emanuel PD, Seeger RC. Expression of CD1d by myelomonocytic leukemias provides a target for cytotoxic NKT cells. Leukemia. 2003;17(6):1068-1077.

33. Wu L, Gabriel CL, Parekh VV, Van Kaer L. Invariant natural killer T cells: innate-like T cells with potent immunomodulatory activities. Tissue Antigens. 2009;73(6):535-545.

34. Haeryfar SM. Invariant natural killer $\mathrm{T}$ cells in immune surveillance and tumor immunotherapy: perspectives and potentials. Arch Iran Med. 2008; 11(2):186-195

35. Van Kaer L. Natural killer T cells as targets for immunotherapy of autoimmune diseases. Immunol Cell Biol. 2004;82(3):315-322.

36. Taams LS, Akbar AN. Peripheral generation and function of CD4+CD25+ regulatory T cells. Curr Top Microbiol Immunol. 2005;293:115-131.

37. Liu Y, Teige I, Birnir B, Issazadeh-Navikas S. Neuron-mediated generation of regulatory $T$ cells from encephalitogenic T cells suppresses EAE. Nat Med. 2006;12(5):518-525.
38. Van Kaer L. Regulation of immune responses by CD1d-restricted natural killer T cells. Immunol Res. 2004;30(2):139-153

39. Novak J, Beaudoin L, Griseri T, Lehuen A. Inhibition of $\mathrm{T}$ cell differentiation into effectors by NKT cells requires cell contacts. J Immunol. 2005; 174(4):1954-1961.

40. Hegde S, Chen X, Keaton JM, Reddington F, Besra GS, Gumperz JE. NKT cells direct monocytes into a DC differentiation pathway. J Leukoc Biol. 2007; 81(5):1224-1235

41. Chen YG, et al. Activated NKT cells inhibit autoimmune diabetes through tolerogenic recruitment of dendritic cells to pancreatic lymph nodes. Jimmunol. 2005;174(3):1196-1204.

42. Campos RA, et al. Cutaneous immunization rapidly activates liver invariant Valpha14 NKT cells stimulating B-1 B cells to initiate $T$ cell recruitment for elicitation of contact sensitivity. J Exp Med. 2003;198(12):1785-1796.

43. Mak TW, Rahemtulla A, Schilham M, Koh DR, Fung-Leung WP. Generation of mutant mice lacking surface expression of CD4 or CD8 by gene targeting. J Autoimmun. 1992;5 suppl A:55-59.

44. Smiley ST, Kaplan MH, Grusby MJ. Immunoglobulin $\mathrm{E}$ production in the absence of interleukin-4-secreting CD1-dependent cells. Science. 1997;275(5302):977-979.

45. Teige A, Bockermann R, Hasan M, Olofsson KE, Liu Y, Issazadeh-Navikas S. CD1d-dependent NKT cells play a protective role in acute and chronic arthritis models by ameliorating antigen-specific Th1 responses. J Immunol. 2010;185(1):345-356.

46. Holmdahl R. Genetics of susceptibility to chronic experimental encephalomyelitis and arthritis. Curr Opin Immunol. 1998;10(6):710-717.

47. Chiba A, Oki S, Miyamoto K, Hashimoto H, Yamamura T, Miyake S. Suppression of collagen-induced arthritis by natural killer T cell activation with $\mathrm{OCH}$, a sphingosine-truncated analog of alpha-galactosylceramide. Arthritis Rheum. 2004;50(1):305-313.

48. Teige I, et al. IFN-beta gene deletion leads to augmented and chronic demyelinating experimental autoimmune encephalomyelitis. I Immunol. 2003;170(9):4776-4784. 